\title{
A Reconnaissance for Signs of a Mississippi Valley-Type Lead-Zinc Mineralizing System on the Eastern Flank of the Rutbah Uplift, Anbar Province, Iraq
}

Open-File Report 2014-1240 



\section{A Reconnaissance for Signs of a Mississippi Valley-Type Lead-Zinc Mineralizing System on the Eastern Flank of the Rutbah Uplift, Anbar Province, Iraq}

By Timothy S. Hayes, Mazin Mustafa, and Thair Benni

Prepared in cooperation with the Iraq Geological Survey under the auspices of the U.S. Department of Defense, Task Force for Business and Stability Operations

Open-File Report 2014-1240

U.S. Department of the Interior

U.S. Geological Survey 


\section{U.S. Department of the Interior \\ SALLY JEWELL, Secretary}

\section{U.S. Geological Survey \\ Suzette M. Kimball, Acting Director}

U.S. Geological Survey, Reston, Virginia: 2014

For more information on the USGS—-the Federal source for science about the Earth,

its natural and living resources, natural hazards, and the environment-visit

http://www.usgs.gov or call 1-888-ASK-USGS (1-888-275-8747)

For an overview of USGS information products, including maps, imagery, and publications, visit http://www.usgs.gov/pubprod

To order this and other USGS information products, visit http://store.usgs.gov

Any use of trade, firm, or product names is for descriptive purposes only and does not imply endorsement by the U.S. Government.

Although this information product, for the most part, is in the public domain, it also may contain copyrighted materials as noted in the text. Permission to reproduce copyrighted items must be secured from the copyright owner.

Suggested citation:

Hayes, T.S., Mustafa, M., and Benni, T., 2014, A reconnaissance for signs of a Mississippi Valley-type lead-zinc mineralizing system on the eastern flank of the Rutbah Uplift, Anbar Province, Iraq: U.S. Geological Survey OpenFile Report 2014-1240, 28 p., http://dx.doi.org/10.3133/ofr20141240.

ISSN 2331-1258 (online) 


\section{Contents}

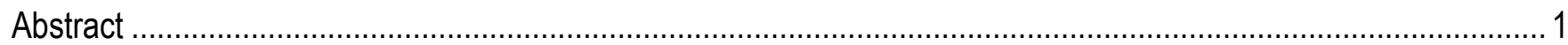

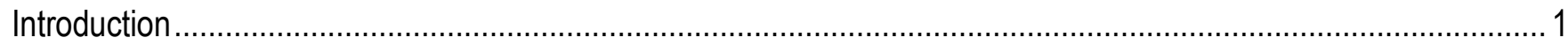

Mississippi Valley-Type Mineralizing System Characteristics and Their Possible Analogues on the Rutbah Uplift ....3

Location 1-Coarse-Crystalline Hydrothermal Dolomite or Calcite.................................................................... 7

Location 2-Najmah Formation Limestone Immediately Beneath the J-K Unconformity and

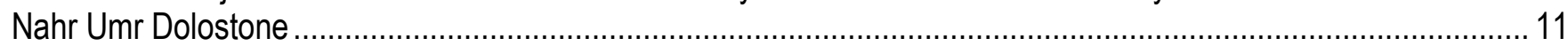

Locations 2(D, E) and 5-Residual Goethite Concentration in a Shallow Depression within Najmah Formation

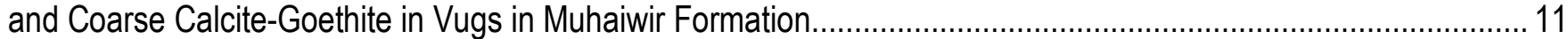

Location 3-Mauddud Formation as Host Rock for a MVT Deposit.................................................................... 14

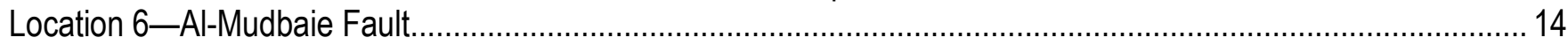

Location 7-Brecciated Carbonate Rock in the Muhaiwir Formation ................................................................... 17

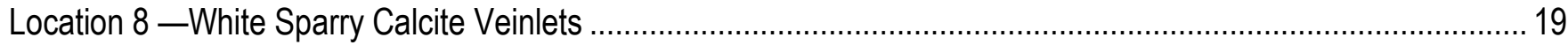

Location 4-Hussainiyat Ironstone Deposit and Its Possible Relation to a MVT Mineralizing System....................... 24

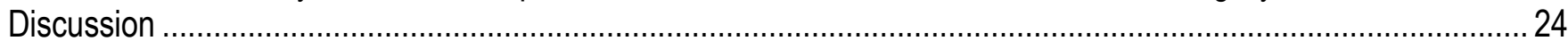

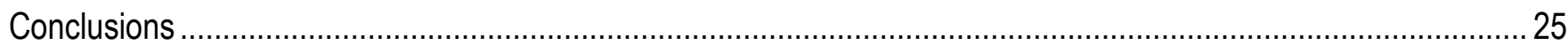

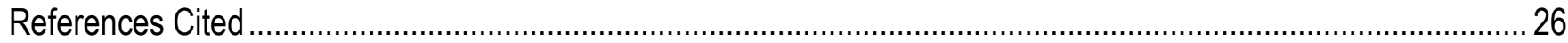

Figures

Figure 1. Map showing tectonic setting of Rutbah Uplift, Anbar Province, Iraq .................................................. 2

Figure 2. Idealized sketch cross section showing stratigraphic and structural situations where interaquifer groundwater mixing occurs, leading to formation of Mississippi Valley-type lead-zinc deposits .............................. 5

Figure 3. Map showing geology of Rutbah Uplift and locations examined and sampled (squares associated with location numbers 1-8) in this reconnaissance study, Anbar Province, Iraq

Figure 4. Photomicrographs in reflected light showing goethite that probably is pseudomorphic after preweathering iron sulfide minerals, from near top of Najmah Formation 500 meters northeast of location 2 (see fig. 3), Rutbah Uplift, Anbar Province, Iraq 12

Figure 5. Energy dispersive spectrum of goethite from the Najmah Formation showing possible lead or molybdenum peaks, Rutbah Uplift, Anbar Province, Iraq.

Figure 6. Photograph showing zone of float pieces of sandstone with black manganese oxides on joints and bedding surfaces extending from left to right across middle ground between the large arrows, Al-Mudbaie Fault, Rutbah Uplift, Anbar Province, western Iraq

Figure 7. Photomicrograph in transmitted, cross-polarized light, of sandstone from silicified and manganesemineralized sandstone along the Al-Mudbaie Fault at location 6 (see fig. 3), Rutbah Uplift, Anbar Province, western Iraq.

Figure 8. Outcrop photograph showing crackle-brecciated dolostone wallrock on the flank of a small depression that probably sits atop paleokarst and contains hematite-kaolinite-veined dolostone and hematitequartz-cemented sandstone, Rutbah Uplift, Anbar Province, western Iraq.

Figure 9. Finely ground slabs stained by the method of Dickson (1965), comparing staining colors of two samples from the Illinois-Kentucky-Central Tennessee Mississippi Valley-Type system, United States (left and center), with sample Jh-3 from dolostone from the Upper Unit of Hussainiyat Formation at location 8 (see fig. 3), Rutbah Uplift, Anbar Province, western Iraq (right) 
Figure 10. Energy dispersive spectrum and standardless semiquantitative analysis of Hussainiyat veinlet calcite from sample Jh-3 from location 8 (see figs. 3 and 9 [right]), Rutbah Uplift, Anbar Province, western Iraq..... 21 Figure 11. Photomicrograph in transmitted, cross-polarized light of the veinlet margin of the calcite-goethite veinlet in sample Jh-3 from location 8 (see figs. 3 and 9 [right]), Rutbah Uplift, Anbar Province, Iraq .....

\section{Tables}

Table 1. Locations visited on the northeastern flank of the Rutbah Uplift and the purpose(s) of visiting each location, Anbar Province, western Iraq.

Table 2. Inductively coupled plasma atomic emission spectrometric and mass spectrometric elemental analyses of goethite from Najmah Formation, Rutbah Uplift, Anbar Province, Iraq.

\section{Conversion Factors}

International System of Units to Inch/Pound

\begin{tabular}{lcll}
\hline & Multiply & & To obtain \\
\hline millimeter (mm) & Length & \\
meter (m) & 0.03937 & inch (in.) \\
kilometer (km) & 3.281 & foot (ft) \\
kilometer (km) & 0.6214 & mile (mi) \\
meter (m) & 0.5400 & mile, nautical (nmi) \\
\hline
\end{tabular}

Temperature in degrees Celsius $\left({ }^{\circ} \mathrm{C}\right)$ may be converted to degrees Fahrenheit $\left({ }^{\circ} \mathrm{F}\right)$ as ${ }^{\circ} \mathrm{F}=\left(1.8 \times{ }^{\circ} \mathrm{C}\right)+32$.

\section{Abbreviations}

$\begin{array}{ll}\text { DOD } & \text { U.S. Department of Defense } \\ \text { EDS } & \text { energy dispersive spectra } \\ \text { EPA } & \text { U.S. Environmental Protection Agency } \\ \text { ppm } & \text { parts per million } \\ \text { MVT } & \text { Mississippi Valley-Type } \\ \text { SEM } & \text { scanning electron microscopy } \\ \text { USGS } & \text { U.S. Geological Survey }\end{array}$




\title{
A Reconnaissance for Signs of a Mississippi Valley- Type Lead-Zinc Mineralizing System on the Eastern Flank of the Rutbah Uplift, Anbar Province, Iraq
}

\author{
By Timothy S. Hayes ${ }^{1}$, Mazin Mustafa², and Thair Benni²
}

\begin{abstract}
Reconnaissance field visits and rock sampling were conducted at eight geologically selected locations within Mesozoic rocks on the eastern flank of the Rutbah Uplift, Anbar Province, western Iraq, in an attempt to determine if these rocks have been affected by a Mississippi Valley-Type (MVT) lead-zinc mineralizing system. Samples subsequently were studied by carbonate mineral staining, transmitted and reflected light petrology, and scanning electron microscopy with semi-quantitative energy dispersive elemental analyses. Single samples were studied by each, inductively coupled plasma mass spectrometry analyses of trace elements and fluid inclusion microthermometry. Permissive evidence indicates that there has been a MVT system present, but none of the evidence is considered definitive.
\end{abstract}

\section{Introduction}

The Rutbah Uplift or Rutbah Dome in Anbar Province, western Iraq, is a foreland swell on the northeastern leading edge of the Arabian Platform, which is being rafted into the continental collision with the southwestern edge of the Asian continent (fig. 1). The foreland basins of the Tigris-Euphrates Plain and Gulf of Arabia are to the northeast and southeast of the Rutbah Uplift, respectively. Farther to the northeast is the active collision belt of the Zagros Mountains, marking the farthest northeastern extent of the former Arabian continental plate that rifted away from Africa at the opening of the Red Sea, beginning in the early Tertiary (Coleman, 1977), and also marking the farthest southwestern extent of the opposing Asian continental plate. Foreland swells cratonward from collisional orogenic mountain belts are common locations for Mississippi Valley-Type (MVT) lead-zinc (Pb-Zn) deposits (Bradley and Leach, 2003).

\footnotetext{
${ }^{1}$ U.S. Geological Survey.

${ }^{2}$ Iraq Geological Survey.
} 


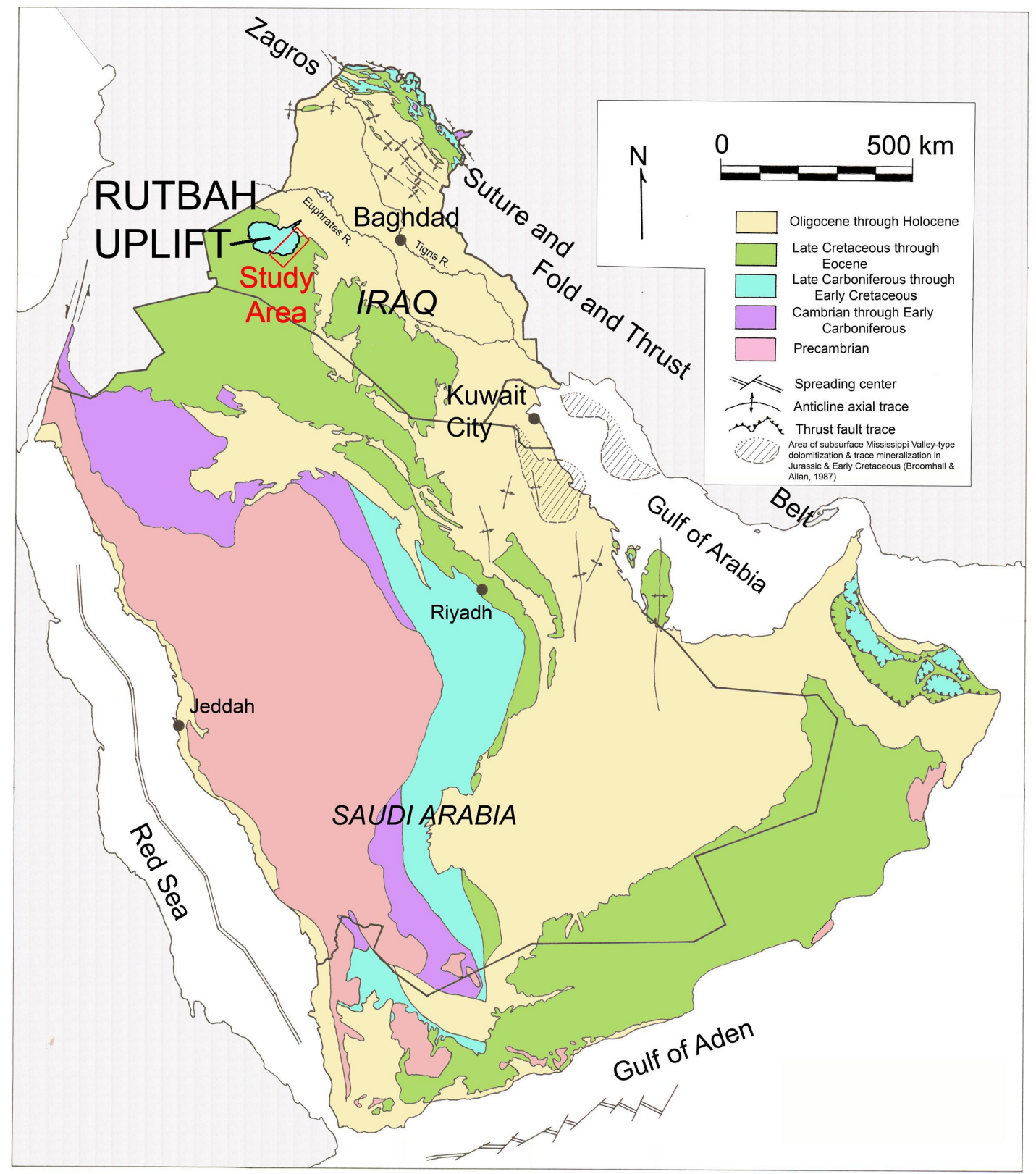

Figure 1. Map showing tectonic setting of Rutbah Uplift, Anbar Province, Iraq. Geology from Hayes and others (2000) and Sissakian (2000). In the folded and thrusted regions, the geology is partly schematic with thrust faults inferred to emplace older rocks atop younger rocks. Diagonal-line areas in northeastern Saudi Arabia and in the Gulf of Arabia contain Mississippi Valley-type dolomitization and mineralization in Late Jurassic and Early Cretaceous carbonates (Broomhall and Allan, 1987; Hayes and others, 2000). 
The objective of this study is to compare rock characteristics of Mississippi Valley-Type (MVT) Pb-Zn mineralizing systems (Leach and others, 2010) to rock characteristics on the Rutbah Uplift of western Iraq, an area identified as a favorable terrain for MVT Pb-Zn deposits. The study evaluates features of formations of ages from Early Jurassic through Early Cretaceous that crop out on the eastern flank of the uplift in order to determine if there is evidence that suggests these rocks have been affected by the migration of MVT metal-rich fluids. The area was selected because of the uplift (foreland swell) and because formations of the same age interval in northeastern Saudi Arabia are known to have been affected by a MVT system (Broomhall and Allen, 1987; Hayes and others, 2000). The first section following provides an overview of MVT deposits, and following sections discuss seven features that are characteristic of MVT systems and that were searched for in the rocks of the Rutbah uplift. The seven features are:

A. Regionally distributed coarse-crystalline hydrothermal dolomite or calcite in aquifer units;

B. Limestone-dolostone interfaces forming the locus for mineralization;

C. Dolostone host rocks;

D. Anomalous concentrations of pyrite or marcasite regionally distributed in aquifer units;

E. Geochemical anomalies in iron $(\mathrm{Fe})$ and manganese $(\mathrm{Mn})$ sited in the regionally distributed hydrothermal carbonates, and geochemical anomalies in $\mathrm{Pb}, \mathrm{Zn}$, copper $(\mathrm{Cu})$, nickel (Ni), cobalt (Co), molybdenum (Mo), and silver ( $\mathrm{Ag}$ ) sited in pyrite, marcasite, and organic matter, also regionally distributed in aquifer units;

F. High-angle faults used as conduits in cross-stratal transport between aquifers and showing anomalous carbonates, iron sulfides, and organic matter, and the anomalous suite of elements in feature (E); and

G. Various types of breccias in carbonate rocks, both pre-ore and syn-ore, that also have anomalous mineral abundances and metals.

These seven features were searched for during field visits and sampling activities.

\section{Mississippi Valley-Type Mineralizing System Characteristics and Their Possible Analogues on the Rutbah Uplift}

MVT $\mathrm{Pb}-\mathrm{Zn}$ deposits are epigenetic, stratabound deposits hosted in carbonate rocks and dominated by galena and sphalerite but also including minor to major amounts of fluorspar and barite in some districts. Such deposits have been mined on every continent except Antarctica (Leach and others, 2010). Deposits of this type have simple mineralogy including galena and sphalerite, typically with greater concentrations ( $>3$ and as much as 15 volume percent) of pyrite and/or marcasite, and with hydrothermal dolomite, calcite, and minor to locally abundant quartz as the important gangue minerals. Combined $\mathrm{Pb}$ and $\mathrm{Zn}$ concentrations typically are 3-12 weight percent. MVT deposits typically have minor concentrations of chalcopyrite and may have many different additional sulfide minerals in trace concentrations. 
The origins of MVT deposits are relatively well understood. In paleohydrologic terms, deposits form within carbonate aquifer rocks in interaquifer groundwater mixing zones where groundwater from a lower aquifer escapes confinement and mixes and reacts with groundwater of the host aquifer above. Regionally, both aquifers are under artesian heads (that is, confined). Fluid inclusion data suggest that the groundwaters of both aquifers in almost all MVT systems are hydrogen sulfide $\left(\mathrm{H}_{2} \mathrm{~S}\right)$-stable deep basinal brines at temperatures from about $80{ }^{\circ} \mathrm{C}$ to about 200 C (Sverjensky, 1981; Plumlee and others, 1994, 1995; Stoffel and others, 2008; Leach and others, 2010, p. 25). Salinities of these groundwaters are from 15 to greater than 25 equivalent weight percent sodium chloride $(\mathrm{NaCl})$, and they are complex brines typically containing large concentrations of calcium and magnesium, as well as sodium and potassium (Leach and others, 2005). Several pathways that may result in interaquifer groundwater mixing zones in a stack of regionally confined carbonate and sandstone aquifers and their confining beds are shown in figure 2. The briny groundwaters that mixed to yield MVT deposits are believed to be derived from fluids recharged in collision-belt mountains before traveling down to great depths through the adjacent foreland basins, where they became hot, saline, and metals-loaded before moving toward discharge zones updip on adjacent cratonal margins (Bethke, 1986; Leach and Rowan, 1986; Appold and Nunn, 2005). That flow system explains why foreland swells are ideal locations for MVT mineralization: foreland swells are structurally high, and mineralizing fluids move upward owing to the artesian heads. It is the cross-stratal escape of groundwater of a lower aquifer mixing upwards with the groundwater from a higher aquifer that produces ore deposition. The ore is deposited in the higher aquifer, below a confining bed. Flow of single brines of MVT systems through hundreds of kilometers laterally within a confined aquifer leaves behind trace mineralization in the form of Fe- and Mn-rich hydrothermal dolomite or calcite, and pyrite, marcasite, and solid organic matter that host anomalous concentrations of $\mathrm{Pb}, \mathrm{Zn}, \mathrm{Cu}, \mathrm{Ni}, \mathrm{Co}$, Mo, and Ag (Erickson and others, 1981; R.E. Erickson, oral commun., 1985; Rowan, 1986; Hayes and others, 1990; Hayes and Anderson, 1992). The minerals of the MVT system either crustify secondary porosity within the carbonate rocks or replace the original carbonate rocks. In the Ozark region in the type area of MVT deposits in the Mississippi River valley of the central United States, zones of anomaly in these metals and minerals from a single MVT system are known in greater than $200,000 \mathrm{~km}^{3}$ of rock (an area of $400 \times 500 \mathrm{~km}$ over an average stratigraphic thickness of greater than $1 \mathrm{~km}$ ). Within that enormous volume, deposits are proportionally very small, with the largest of them measuring about $100 \mathrm{~m}$ wide, $50 \mathrm{~m}$ thick, and, rarely, as much as $20 \mathrm{~km}$ long. One kilometer long or less would be more typical for an individual deposit, although the deposits do tend to align, in one place making a continuously mineralized trend more than $100 \mathrm{~km}$ long.

As the work reported here began, it was known that rocks in northeastern Saudi Arabia that are correlatable with those exposed on the flanks of the Rutbah Uplift have been affected by a MVT mineralizing system (Broomhall and Allan, 1987; Hayes and others, 2000, p. 7-9). The MVT mineralization there only has been identified from drill core from depths greater than $2 \mathrm{~km}$ (where a MVT deposit would not be economical to mine by conventional methods) and from more than $350 \mathrm{~km}$ southeast of the study area, near the Gulf of Arabia coast of Saudi Arabia (fig. 1). 


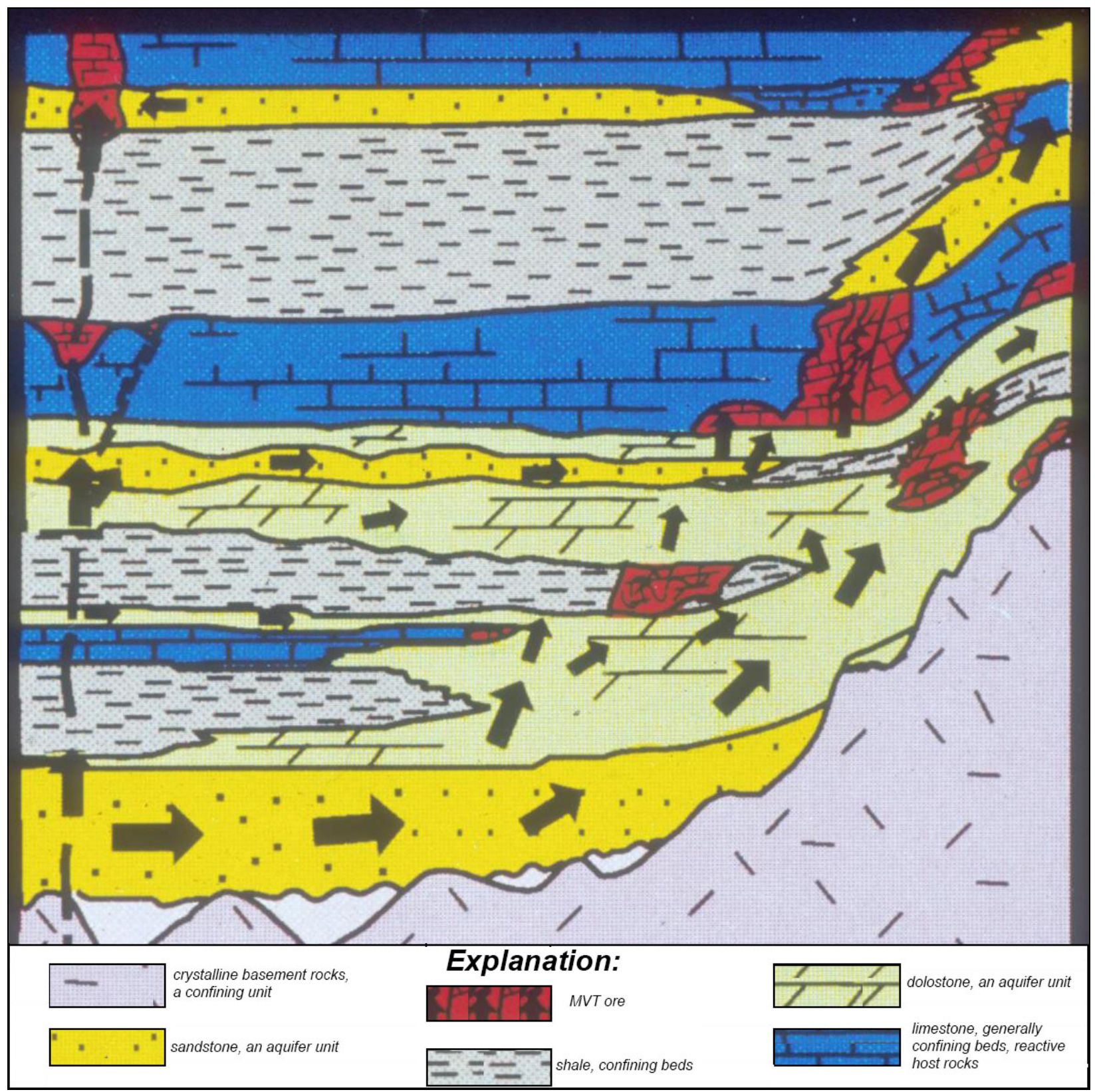

Figure 2. Idealized sketch cross section showing stratigraphic and structural situations where interaquifer groundwater mixing occurs, leading to formation of Mississippi Valley-type lead-zinc deposits. Sandstones and dolostones on this sketch are aquifers; shales and most limestones are confining beds. All aquifers apparently had artesian heads (were confined). Prior to ore-stage, the rock volumes that became orebodies were limestone, and they were dolomitized as part of the ore processes. Inferred directions of movement of mineralizing brines are shown with arrows. 
Additionally in Saudi Arabia, the Paleozoic through Early Cretaceous rocks that crop out on the flanks of the Precambrian core of the Saudi Arabian craton have been affected by an epigenetic mineralizing process referred to as "ferruginization" (Vaslet and others, 1983; Smith, 1984a, 1984b; Smith and Allen, 1984; Hayes and others, 2000, p. 17-19). In ferruginized sections, the upper parts of aquifer units, sandstones, or carbonates, and the bottom parts of the overlying confining beds are mineralized with goethite and lesser hematite, and the rock has anomalous concentrations of $\mathrm{Fe}, \mathrm{Mn}, \mathrm{Zn}$, and $\mathrm{Pb}$. Whole rock analyses of ferruginized rocks indicate that these rocks contain 1-18 percent Fe, 75 parts per million (ppm) to 1.25 percent $\mathrm{Mn}$, as much as 2,000 ppm Zn, and as much as 1,000 ppm Pb (Smith, 1984a,1984b; Vaslet and others, 1994). Ferruginization is interpreted to record only that these metals were transported through the aquifers. Analogous effects were noted along the top of the Lamotte Sandstone and the bottom of the Bonneterre Dolomite of the Ozark Region MVT System (Gregg, 1985; Hayes and others, 2000, p. 18). We questioned whether the epigenetic iron mineralization of goethite and hematite near the top of the Permian Ga'ara Formation on the Rutbah Uplift (Tobia, 1983; Al-Bassam and Hak, 2006) represents ferruginization like that in Saudi Arabia or the Ozark region. We questioned whether the ironstone deposit of the Hussainiyat Formation on the Rutbah Uplift (Al-Bassam and Tamar-Agha, 1998) might also represent ferruginization, like such rocks in Saudi Arabia and the United States.

Finally, the Mesozoic formations exposed in outcrop on the Rutbah Uplift are conducive to MVT mineralization if a system existed, because they mostly are carbonates, both limestones and dolostones, with lesser thicknesses of sandstones and shales. MVT deposits are commonly found within dolostone near lateral contacts between limestone and dolostone (Snyder, 1968, p. 278; Pratt and others, 1986). MVT systems also produce limestone-dolostone interfaces that approximately parallel bedding (Gregg, 1985). In forming MVT deposits, it also is favorable to have shales (confining beds) and sandstones (aquifers) interlayered with carbonates in the local section as shown in figure 2.

A reconnaissance examination of the Middle Jurassic through Lower Cretaceous rocks on the eastern flank of the Rutbah Uplift was done for the reasons stated earlier in this section. Seven specific features characteristic of MVT systems (table 1, letters [A] through [G] in the far right column) were searched for and, where present, were examined in the field and sampled as appropriate. Additional visits were made to examine outcrops of the Mauddud Formation (correlatable with the Saudi Arabian Sulaiy formation, which contains the best MVT mineralization known to date in the subsurface of that country) and to examine the Hussainiyat ironstone deposit (considering whether it might be epigenetic and MVT-related). Samples were studied by (1) combinations of carbonate mineral staining by the method of Dickson (1965), (2) petrologic examination in transmitted and reflected light, (3) scanning electron microscopy (SEM) including both mineral textures and elemental compositions of minerals by energy dispersive spectra (EDS) and standardless semi-quantitative analyses of those spectra, and (4) for a single sample, by 4-acid digestion inductively coupled plasma mass spectrometric elemental analysis. Another single sample was examined for a possible fluid inclusion microthermometry study, but it lacked any suitable fluid inclusions. 
Fieldwork was done over a 4-day period in May and June 2010, but totaled probably less than 10 hours spent examining and sampling outcrops because of long drive times to the Rutbah Uplift from the camp.

The seven specific features of MVT systems that were searched for on the Rutbah Uplift are discussed in following sections, followed by discussion of the Hussainiyat ironstone deposit in the context of MVT mineralization. Locations are listed in the sequence that they were visited in the fieldwork (table 1). Features are listed from $\mathrm{A}$ to $\mathrm{G}$ in the order listed earlier but were not visited in that sequence. The discussion section then provides interpretations and summarizes the findings.

\section{Location 1-Coarse-Crystalline Hydrothermal Dolomite or Calcite}

Hydrothermal dolomite or calcite of Mississippi Valley-type mineralizing systems is both characteristic and conspicuous. Individual crystals of such dolomite that have grown into secondary porosity sites have curved crystal axes and are referred to as saddle dolomite (Radke and Mathis, 1980). In thin section, such dolomite crystals have sweeping extinction as the microscope stage is rotated with polarizer and analyzer crossed. Additionally, the hydrothermal dolomite generally is anomalously rich in Fe and Mn (Farr, 1989), or where the hydrothermal carbonate is calcite, the calcite is anomalously rich in Fe and Mn (Hayes and Anderson, 1992).

The coarsest crystalline dolomite on the eastern flank of the Rutbah Uplift in Iraq is at and near the base of the Upper Unit of the Middle Jurassic Hussainiyat Formation in outcrops flanking the valley of Wadi Hauran. These outcrops were visited at location 1 (table 1, fig. 3). Dolostone in these outcrops is from 150 to $700 \mu \mathrm{m}$ in grain size (fine- to coarse-crystalline). Individual dolomite crystals are not saddle dolomite, the crystal axes are not curved, the crystals do not have sweeping extinction, and dolomite crystals did not grow into sites of secondary porosity. For about $2 \mathrm{~m}$ upward from the top of Lower Unit Hussainiyat shales, the Upper Unit Hussainiyat dolostone is intensely dedolomitized (Hasan, 1993). The outcrops also are cut by sparse $1 \mathrm{~mm}$-thick veinlets of very coarse-crystalline white calcite with veinlet selvages of goethite (see, also, section, "Location 8-White Sparry Calcite Veinlets"). Reflected light microscopy showed the goethite to be composed of aggregates of 80 - to $150-\mu \mathrm{m}$ microspheres, almost certainly a primary precipitate of goethite, not a pseudomorph of an earlier iron sulfide. EDS spectra of the calcite at location 1 from an examination by scanning electron microscope showed no Fe or Mn peaks, and standardless semiquantitative analyses of those spectra yielded iron concentrations of no more than 0.4 weight percent Fe and 0.1 weight percent $\mathrm{Mn}$. The dolomite at the base of the Upper Hussainiyat, therefore, is not interpreted to be of epigenetic hydrothermal origin. 


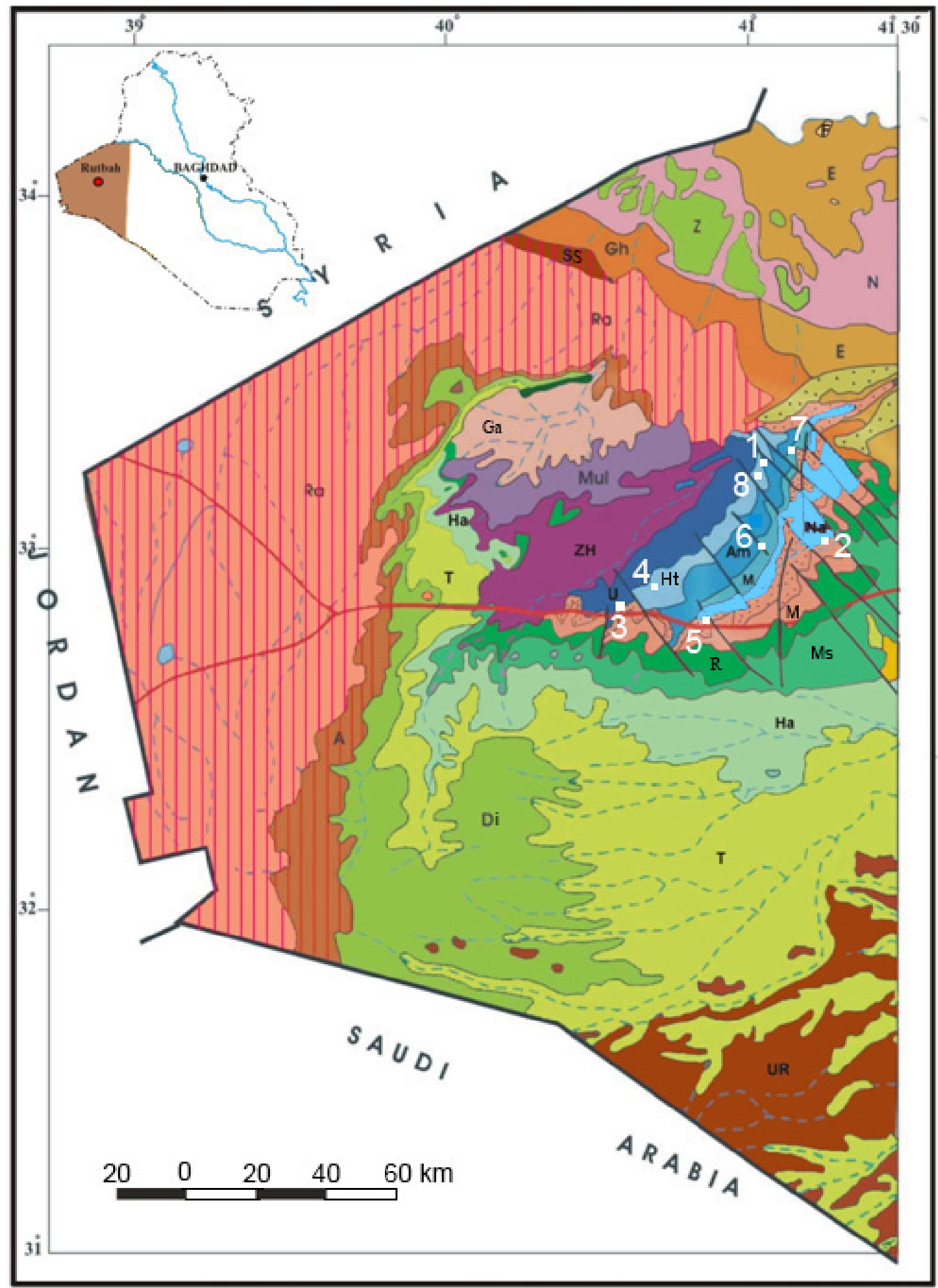

Figure 3. Map showing geology of Rutbah Uplift and locations examined and sampled (squares associated with location numbers 1-8) in this reconnaissance study, Anbar Province, Iraq. Geology from Sissakian (2007). 


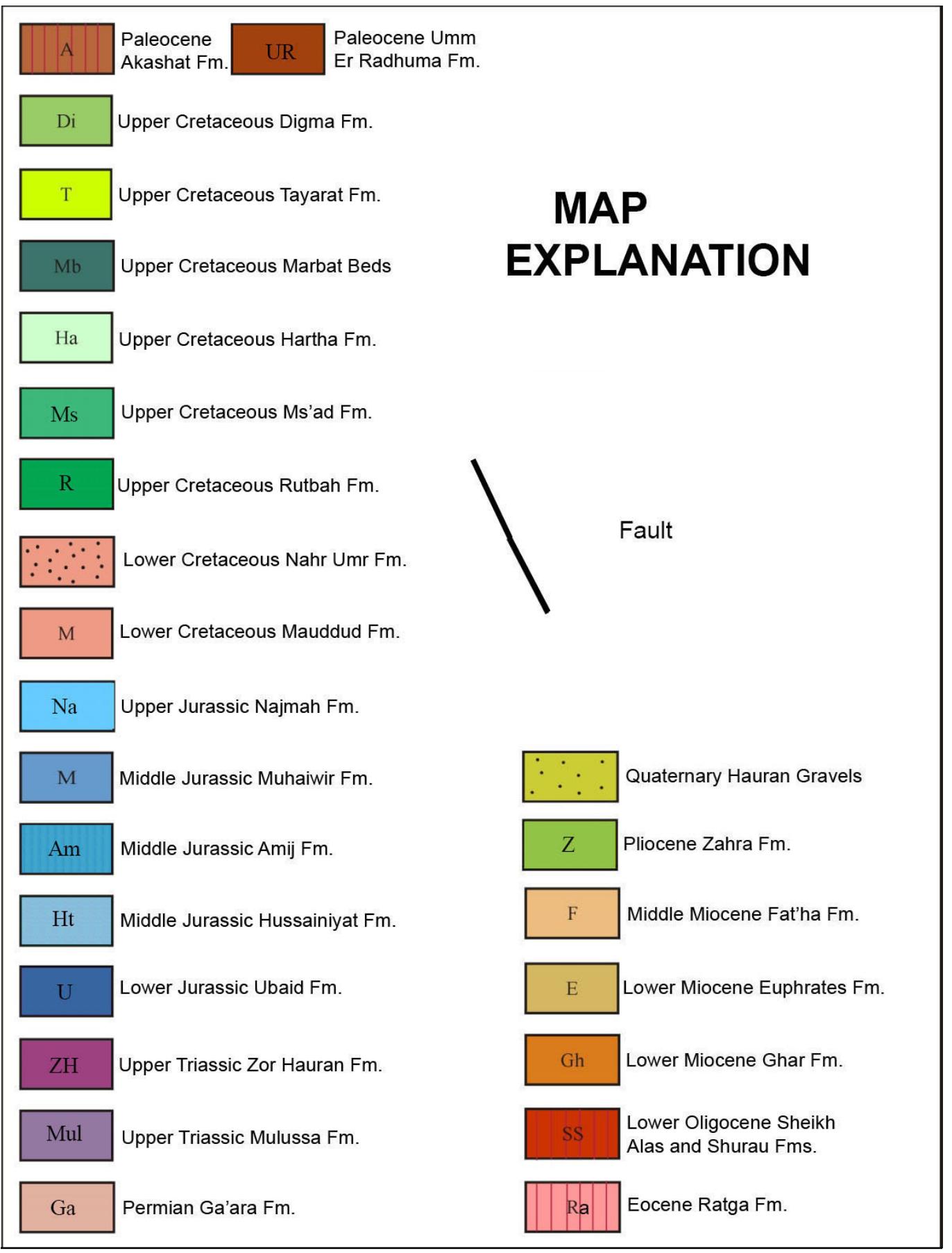

Figure 3.-Continued 


\section{Table 1. Locations visited on the northeastern flank of the Rutbah Uplift and the purpose(s) of visiting each location, Anbar Province, western Iraq.}

[Each location was visited in order to examine seven specific features characteristic of MVT systems (letters [A] through [G] were searched for and, where present, were examined in the field and sampled as appropriate]

\begin{tabular}{|c|c|c|c|}
\hline $\begin{array}{l}\text { Location No. } \\
\text { (see fig. 3) }\end{array}$ & $\begin{array}{l}\text { Latitude } \\
\text { (degrees, minutes, } \\
\text { decimal minutes) }\end{array}$ & $\begin{array}{l}\text { Longitude } \\
\text { (degrees, minutes, } \\
\text { decimal minutes) }\end{array}$ & Location was visited in order to examine: \\
\hline 1 & $33^{\circ} 26.859^{\prime} \mathrm{N}$ & $41^{\circ} 05.389^{\prime} \mathrm{E}$ & $\begin{array}{l}\text { (A) Coarse crystalline hydrothermal dolomite or calcite. Upper } \\
\text { Unit of the Hussainiyat Formation. }\end{array}$ \\
\hline 2 & $33^{\circ} 15.464^{\prime} \mathrm{N}$ & $41^{\circ} 20.070^{\prime} \mathrm{E}$ & $\begin{array}{l}\text { (B) Mississippi Valley-Type (MVT) ores are localized near } \\
\text { limestone-dolostone interfaces within the dolostone. (This is } \\
\text { site of limestone of Najmah Formation directly overlain by } \\
\text { dolostone of Nahr Umr Formation.) (D) Anomalous } \\
\text { concentrations of pyrite or marcasite regionally distributed } \\
\text { in paleoaquifer units; (E) Geochemical anomaly in lead } \\
(\mathrm{Pb}) \text {, zinc ( } \mathrm{Zn} \text { ), copper (Cu), nickel (Ni), cobalt (Co), } \\
\text { molybdenum (Mo), and silver (Ag) sited in iron sulfides and } \\
\text { organic matter and widespread through regional aquifer } \\
\text { units. (Concentration of residual goethite after iron sulfide } \\
\text { is } 500 \text { meters northeast of this location.) }\end{array}$ \\
\hline 3 & $33^{\circ} 02.963^{\prime} \mathrm{N}$ & $40^{\circ} 35.841^{\prime} \mathrm{E}$ & $\begin{array}{l}\text { (C) Examined Lower Cretaceous Mauddud Formation, } \\
\text { correlative of the Saudi Arabia Sulaiy Formation, which } \\
\text { locally hosts ore-grade MVT mineralization in its } \\
\text { northeastern oil province, although at depths too great for } \\
\text { conventional underground mining. }\end{array}$ \\
\hline 4 & $33^{\circ} 08.077^{\prime} \mathrm{N}$ & $40^{\circ} 42.488^{\prime} \mathrm{E}$ & $\begin{array}{l}\text { Hussainiyat iron mine. Question whether this rock, interpreted } \\
\text { as a typical oolitic ironstone deposit, might instead be } \\
\text { epigenetic and related to a MVT system. Lower Unit of the } \\
\text { Hussainiyat Formation. }\end{array}$ \\
\hline 5 & $\begin{array}{l}\text { approximately } \\
33^{\circ} 02.3^{\prime} \mathrm{N}\end{array}$ & $\begin{array}{l}\text { approximately } \\
40^{\circ} 55.0^{\prime} \mathrm{E}\end{array}$ & $\begin{array}{l}\text { (A,D,E) Coarse-crystalline hydrothermal calcite in vugs. } \\
\text { Geochemical anomaly in } \mathrm{Pb}, \mathrm{Zn}, \mathrm{Cu}, \mathrm{Ni}, \mathrm{Co}, \mathrm{Mo} \text {, and } \mathrm{Ag} \\
\text { sited in iron sulfides and organic matter and widespread } \\
\text { through regional aquifer units. (Goethite is in area of } \mathrm{J} . \\
\text { Muhawir Formation outcrop at this site.) }\end{array}$ \\
\hline 6 & $33^{\circ} 15.596^{\prime} \mathrm{N}$ & $41^{\circ} 05.876^{\prime} \mathrm{E}$ & $\begin{array}{l}\text { (F) Faults are favored conduits for interaquifer fluid transport, } \\
\text { and thus are a common locus of MVT mineralization. (Al- } \\
\text { Mudbaie Fault was examined for evidence of an epigenetic } \\
\text { mineralizing system.) }\end{array}$ \\
\hline 7 & $33^{\circ} 28.288^{\prime} \mathrm{N}$ & $41^{\circ} 07.739^{\prime} \mathrm{E}$ & $\begin{array}{l}\text { (G) MVT deposits and trace mineralization commonly are } \\
\text { hosted by various types of breccias, both pre-ore and ore- } \\
\text { stage in origin. (Examined brecciated rock at the margins of } \\
\text { a collapse structure cutting Muhaiwir Formation near } \\
\text { paleokarst bauxite deposits in the underlying Ubaid } \\
\text { Formation.) }\end{array}$ \\
\hline 8 & $33^{\circ} 26.424^{\prime} \mathrm{N}$ & $41^{\circ} 03.332^{\prime} \mathrm{E}$ & $\begin{array}{l}\text { (A.D.E) Very coarse-grained hydrothermal carbonates with } \\
\text { anomalous Fe and Mn concentrations and commonly } \\
\text { associated with trace sulfides crustify many different types } \\
\text { of secondary porosity or replace wallrocks. The } \\
\text { hydrothermal carbonates are very widespread and found } \\
\text { particularly within regional aquifer units. (Examined } \\
\text { veinlets of sparry white calcite with goethite selvages, this } \\
\text { location.) }\end{array}$ \\
\hline
\end{tabular}




\section{Location 2-Najmah Formation Limestone Immediately Beneath the J-K Unconformity and Nahr Umr Dolostone}

Late Jurassic Najmah Formation outcrops along the Kilo 160 Road at location 2 (table 1, fig. 3) are pristine lime-wackestones with no signs of any hydrothermal mineralization of any kind. These rocks constituted a confining bed for groundwater flow. Disconformably overlying Early Cretaceous Nahr Umr dolostones in the same outcrops are medium-crystalline mosaic dolostone, although the Nahr Umr more typically consists mainly of sandstones with lesser claystones. These dolostones also have no signs of any hydrothermal mineralization.

\section{Locations 2(D, E) and 5-Residual Goethite Concentration in a Shallow Depression within Najmah Formation and Coarse Calcite-Goethite in Vugs in Muhaiwir Formation}

Approximately $500 \mathrm{~m}$ to the northeast of location 2, a shallow topographic depression recessed 1-2 m below the level of Najmah limestone outcrops on its southern, eastern, and western sides was examined. This depression contains a residual concentration of cobble-sized pieces of goethite with obvious layer-form and colloform growth habit. The concentration of goethite is sufficient to yield a desert pavement. In its layer-form and colloform growth habit, the goethite appears similar to goethite observed in "filled-sink" iron deposits in central Missouri, which are considered distal expressions of the Ozark Region Mississippi Valley-type mineralizing system. In filled-sink Fe deposits, the pre-weathering minerals are pyrite and marcasite within typically cylindrical collapse breccia bodies interpreted as the sinks of a pre-ore paleokarst (Grawe, 1945). Iron sulfides of the filled-sinks yield trace-metal anomalies similar to the regionally distributed iron sulfides within confined aquifers that were reported by Erickson and others (1981).

Reflected light microscopy confirmed the layer-form and colloform growth habit of the goethite, and ghost crystals that probably were pseudomorphic after an earlier iron sulfide were also found within the goethite (fig. 4). Energy dispersive spectra (EDS) from the scanning electron microscope (SEM) showed what might be small peaks for $\mathrm{Pb}$ (fig. 5), but none of more than 20 spectra yielded results from standardless semiquantitative analyses in which $\mathrm{Pb}$ was quantifiable (fig. 5, standardless semi-quantitative analysis table in lower left). 


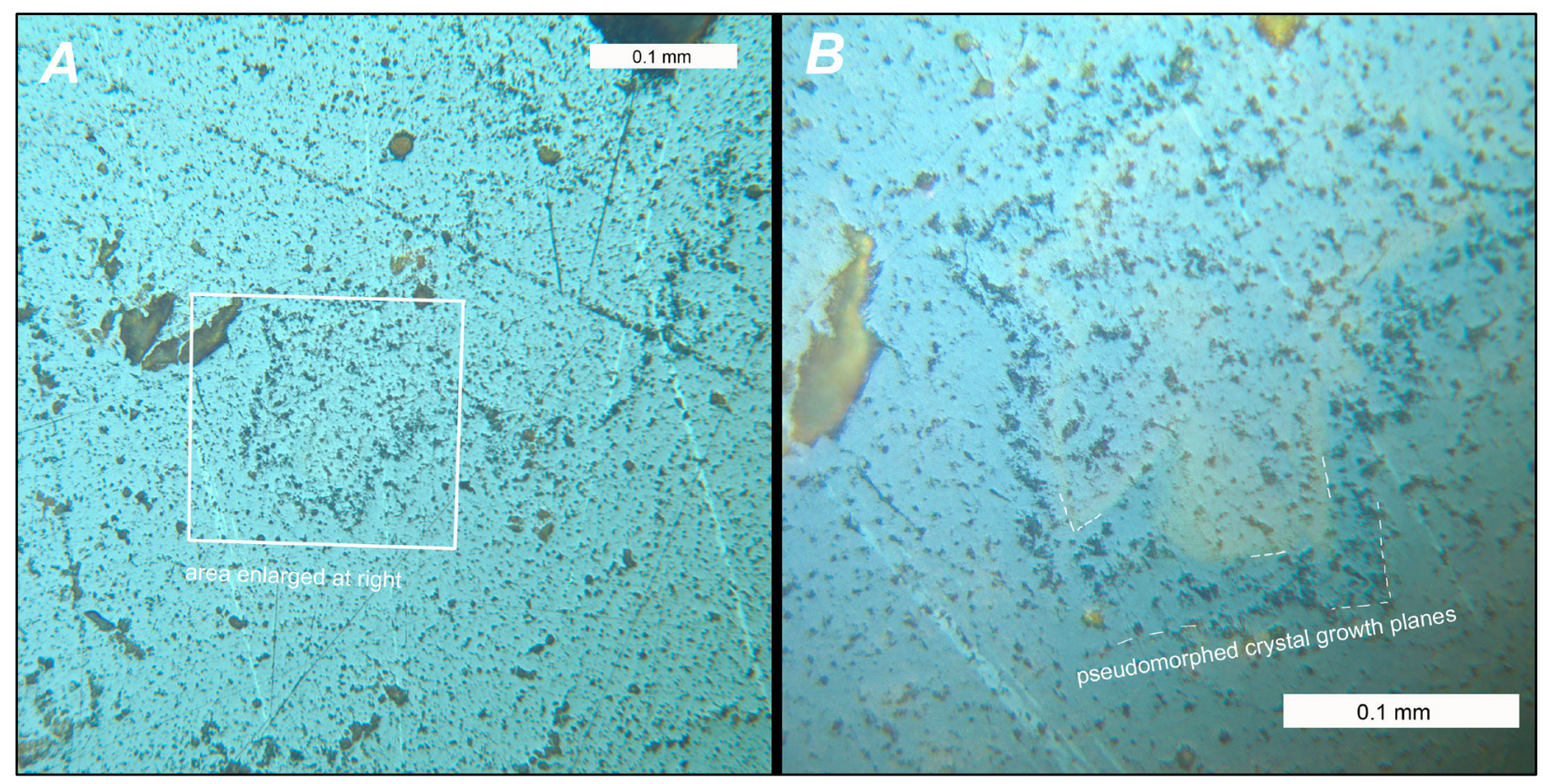

Figure 4. Photomicrographs in reflected light showing goethite that probably is pseudomorphic after preweathering iron sulfide minerals, from near top of Najmah Formation 500 meters northeast of location 2 (see fig. 3), Rutbah Uplift, Anbar Province, Iraq. Frame A is in reflected, plane polarized light, and the rectangle shows the area of frame $B$. Frame $B$ is an enlargement of the rectangular area in $A$ and shows ghost crystals of an earlier iron sulfide visible because of the variable yellow internal reflection within the goethite and because of differences in the abundance of polishing pits.

If this goethite is a pseudomorph of pyrite-marcasite that came from a MVT mineralizing system, and the goethite did not lose trace elements during weathering of its parent iron sulfides, it would be expected to have anomalous concentrations from among the suite of elements $\mathrm{Pb}, \mathrm{Zn}$, $\mathrm{Cu}, \mathrm{Ni}, \mathrm{Co}, \mathrm{Mo}$, and $\mathrm{Ag}$ (Erickson and others, 1981). Typical concentrations of these metals in acid-insoluble residues of the sedimentary rock aquifers that transmitted MVT fluid in the Ozark regional system are more than $100 \mathrm{ppm} \mathrm{Pb}$, more than $300 \mathrm{ppm} \mathrm{Zn}$, more than $50 \mathrm{ppm} \mathrm{Cu}$, more than $50 \mathrm{ppm} \mathrm{Ni}$, more than $50 \mathrm{ppm} \mathrm{Co}$, more than $20 \mathrm{ppm}$ Mo, and more than $1 \mathrm{ppm} \mathrm{Ag}$ (Grawe, 1945, p. 164; R.E. Erickson, U.S. Geological Survey, oral commun., 1985), so the apparent $\mathrm{Pb}$ peaks and suggestions (but not demonstrations) of analyses of greater than 1 percent $\mathrm{Pb}$ in the goethite were potentially important. In a typical single sample from the Ozark system, some but not all metals listed are at anomalous concentrations (R.E. Erickson, U.S. Geological Survey, oral commun., 1985). A split of the goethite rock sample was submitted for analysis by 4-acid digestion inductively coupled plasma mass spectrometry analysis, from which the lower detection limits for these metals are small (generally less than $1 \mathrm{ppm}$ ). The goethite contained 6 ppm Pb, 54 ppm Zn, 10 ppm Cu, 158 ppm Ni, 68 ppm Co, 180 ppm Mo, and less than 1 ppm Ag (table 2). Molybdenum has peaks close to those peaks labeled lead or molybdenum peaks on figure 5, and molybdenum is, thus, responsible for the small peaks on the EDS spectrum at about $2.03 \mathrm{Kev}$. 


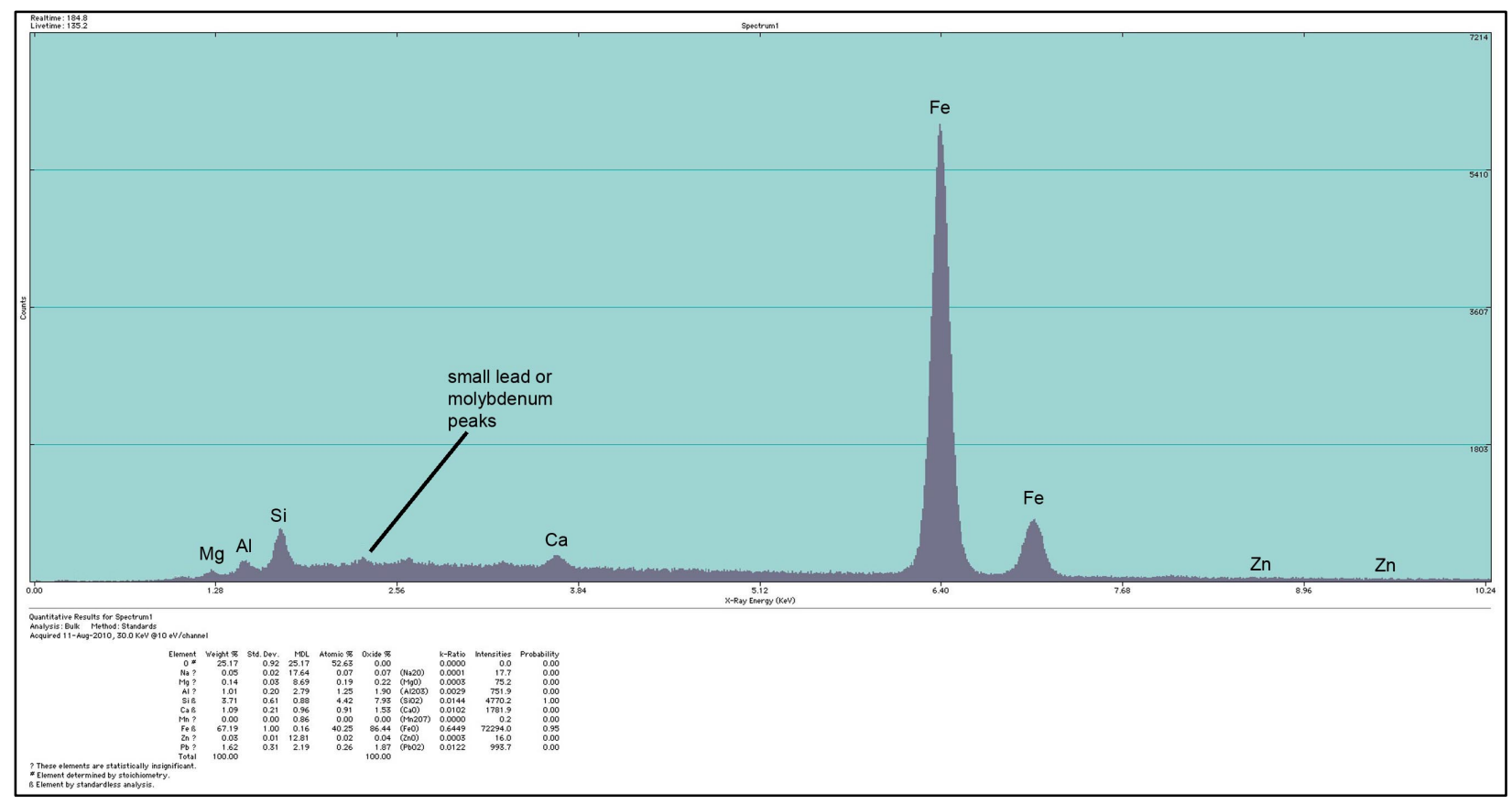

Figure 5. Energy dispersive spectrum of goethite from the Najmah Formation showing possible lead or molybdenum peaks, Rutbah Uplift, Anbar Province, Iraq. Graph shows spectrum, and table at bottom shows results of standardless semi-quantitative elemental analysis from spectrum with small peaks modeled as lead peaks. Question marks after an element abbreviation in the elemental analyses indicate that the peak position of the element did not receive a statistically significant proportion of the total number of counts so that, in a rigorous examination of the results, that element should be considered to be in a concentration below detection limits.

Table 2. Inductively coupled plasma atomic emission spectrometric and mass spectrometric elemental analyses of goethite from Najmah Formation, Rutbah Uplift, Anbar Province, Iraq.

[Analytical results are listed alphabetically by the abbreviation for the 49 selected elements. Analytical procedure: sample is first decomposed using a sodium peroxide sinter at 450 degrees Celsius. The solid then is leached with water and acidified with concentrated nitric acid. Tartaric acid is added, and aliquots of the digested sample are aspirated into the Inductively Coupled Plasma Atomic Emission Spectroscopy (ICP-AES) and the Inductively Coupled Plasma Mass Spectroscopy (ICP-MS).

Elements: Ag, silver; Al, aluminum; As, arsenic; $\mathrm{Ba}$, barium; Be, beryllium; Bi, bismuth; Ca, calcium; Cd, Cadmium; Ce, cerium; Co, cobalt; $\mathrm{Cr}$, chromium; Cs, cesium; $\mathrm{Cu}$, copper; Fe, iron; Ga, gallium; In, indium; K, potassium; La, lanthanum; Li, lithium; Mg, magnesium; Mn, manganese; Mo, molybdenum; Na, sodium; Nb, niobium; Ni, nickel; $\mathrm{P}$, phosphorus; $\mathrm{Pb}$, lead; $\mathrm{Rb}$, rubidium; S, sulfur; Sb, antimony; Sc, scandium; Sn, tin; Sr, strontium; Te, tellurium; Ti, titanium; Th, thorium; Tl, thallium; U, uranium; V, vanadium; W, tungsten; Y, yttrium; Zn, zinc. Abbreviation and symbols: ppm, parts per million; <, less than; >, greater than; \%, percent]

\begin{tabular}{|c|c|c|c|c|c|}
\hline $\mathrm{Ag}<1 \mathrm{ppm}$ & $\mathrm{Al} 0.4 \%$ & As $137 \mathrm{ppm}$ & Ba 714 ppm & Be $12.6 \mathrm{ppm}$ & $\mathrm{Bi}<0.04 \mathrm{ppm}$ \\
\hline $\mathrm{Ca} 0.71 \%$ & $\mathrm{Cd} 0.8 \mathrm{ppm}$ & $\mathrm{Ce} 73.2 \mathrm{ppm}$ & Co 67.6 ppm & $\mathrm{Cr} 67$ ppm & Cs $<5$ ppm \\
\hline $\mathrm{Cu} 9.7$ ppm & $\mathrm{Fe}>15 \%$ & Ga 7.23 ppm & In $<0.02 \mathrm{ppm}$ & K $0.02 \%$ & La 28.6 ppm \\
\hline Li 1 ppm & $\operatorname{Mg} 0.25 \%$ & Mn $271 \mathrm{ppm}$ & Mo 180 ppm & $\mathrm{Na} 0.03 \%$ & $\mathrm{Nb} 5.4 \mathrm{ppm}$ \\
\hline Ni 158 ppm & P 460 ppm & $\mathrm{Pb} 6$ ppm & $\mathrm{Rb} 1.1 \mathrm{ppm}$ & S $0.04 \%$ & $\mathrm{Sb} 1.62 \mathrm{ppm}$ \\
\hline Sc $6.1 \mathrm{ppm}$ & $\mathrm{Sn} 0.2 \mathrm{ppm}$ & Sr $53.1 \mathrm{ppm}$ & $\mathrm{Te}<0.1 \mathrm{ppm}$ & Ti $0.02 \%$ & Th $0.7 \mathrm{ppm}$ \\
\hline $\mathrm{Tl}<0.1 \mathrm{ppm}$ & U $7.6 \mathrm{ppm}$ & V 408 ppm & W 0.7 ppm & Y 79.2 ppm & Zn 54 ppm \\
\hline
\end{tabular}


Another area of anomalous goethite occurrence was examined within an area of Middle Jurassic Muhaiwir Formation dolostone at location 5 (table 1, fig. 3). The goethite at location 5 occurs in vugs, also has layer-form colloform habit, and has small amounts of very coarsegrained white sparry calcite associated with it. No samples were taken at location 5.

\title{
Location 3-Mauddud Formation as Host Rock for a MVT Deposit
}

\begin{abstract}
At location 3 (table 1, fig. 3), outcrops of the Lower Cretaceous Mauddud Formation dolostones along a roadcut were examined. They are pastel red and green, medium crystalline, mosaic dolostones that have birdseyes, veinlets, and small breccias filled with white sparry calcite. Random placement of the birdseyes probably results from their origin in burrows in lime mudstone before dolomitization. Carbonate staining by the method of Dickson (1965) showed that the dolomite is relatively poor in iron, and the calcite has nearly no iron. Although these outcrops generally lack signs of hydrothermal mineralization, the rocks could be suitable host rocks for a MVT deposit. The Maddud dolostones are fully comparable with Bonneterre Formation dolostones remote from mineralization in the Annapolis subdistrict of the Southeast Missouri Lead District.
\end{abstract}

\section{Location 6-Al-Mudbaie Fault}

Carbonate rocks cut by high-angle faults form loci for mineralizing fluids in MVT systems because the faults provide channelways between aquifers (fig. 2). Veins of MVT mineralization may form within the faults.

Exposures of the Al-Mudbaie Fault were examined at and near location 6 (table 1, fig. 3). The trace of the fault is clearly marked between low-relief outcrops of yellowish, very finegrained sandstone of the Middle Jurassic Amij Formation on the west, and slightly higher relief outcrops of red-mottled medium crystalline dolostone of the Middle Jurassic Muhaiwir Formation on the eastern, downthrown side. An elongate lens-shaped zone more than $1 \mathrm{~km}$ long and locally as much as about $30 \mathrm{~m}$ wide lies between these outcrops. The zone has pieces of medium- to coarse-grained sandstone float that all have their joint boundaries and many bedding planes colored black with Mn oxide minerals. The zone appears as a nearly linear strip with black pieces in otherwise light brown desert (fig. 6). Numerous pieces of sandstone float have slickensided surfaces, and additional pieces contain faults of tiny displacement. On freshly broken surfaces, most sandstone pieces appear silicified; they have almost no intergranular porosity and have conchoidal breakage. In thin section, the silicification appears as overgrowths on detrital quartz grains that fill all intergranular porosity and form many concavo-convex grain boundaries (fig. 7). Detritus is more than 98 percent quartz grains with less than 1 percent each of a titanium dioxide $\left(\mathrm{TiO}_{2}\right)$ phase, probably rutile, and tourmaline - the sandstone is a supermature orthoquartzite. Two generations of calcite cement are recognized. Both post-date the quartz overgrowths, and both fill cracks that cross detrital quartz grains. The older of the two calcite generations is poikilotopic (fig. 7), with sand-calcite crystal sizes as large as $2 \mathrm{~mm}$. The younger generation fills fractures that pass through both detritus and the first generation calcite and has micritic crystallinity. The younger generation probably is caliche calcite from the recent weathering.

The zone littered with black-coated sandstone float was followed almost $1 \mathrm{~km}$ northward to where it pinched out. Beyond the pinchout, the fault continued to be easily traced between low outcrops of the two contrasting lithologies. 
The elongate lens of black sandstone float (fig. 6) marks the fault zone and records anomalous mineralogy localized by the fault, namely the black manganese oxides. In the absence of any other primary minerals that can site manganese, it seems that some of the calcite must have been sufficiently manganiferous to produce the black oxides during weathering.

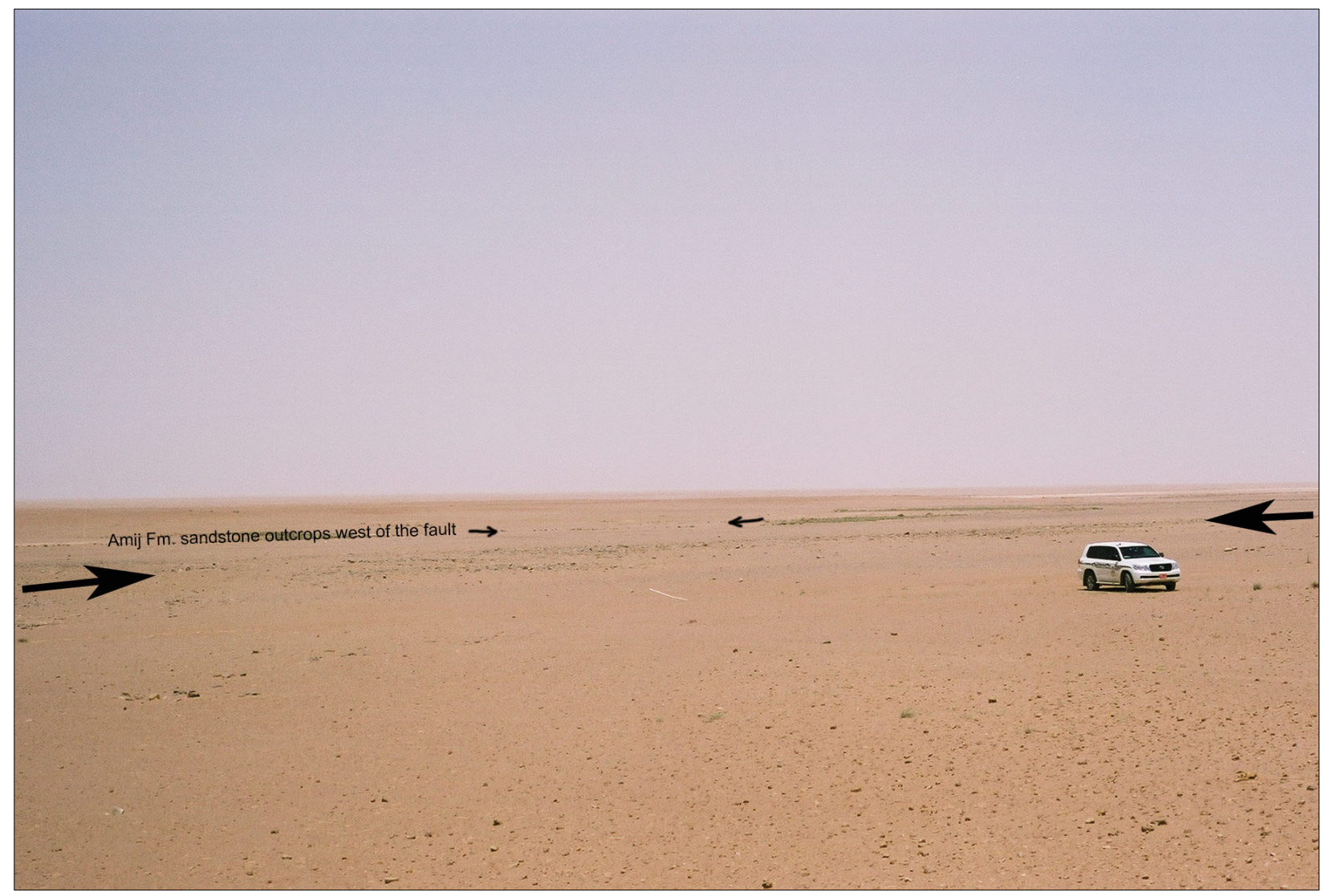

Figure 6. Photograph showing zone of float pieces of sandstone with black manganese oxides on joints and bedding surfaces extending from left to right across middle ground between the large arrows, AlMudbaie Fault, Rutbah Uplift, Anbar Province, western Iraq. Zone marks silicified and manganesemineralized sandstone along Al-Mudbaie Fault. Slightly beyond zone is a series of low outcrops of Amij Formation sandstone. Photographer was standing on an outcrop of Muhaiwir Formation dolostone. Photograph was taken at location 6 (see fig. 3). Field vehicle shows scale. 


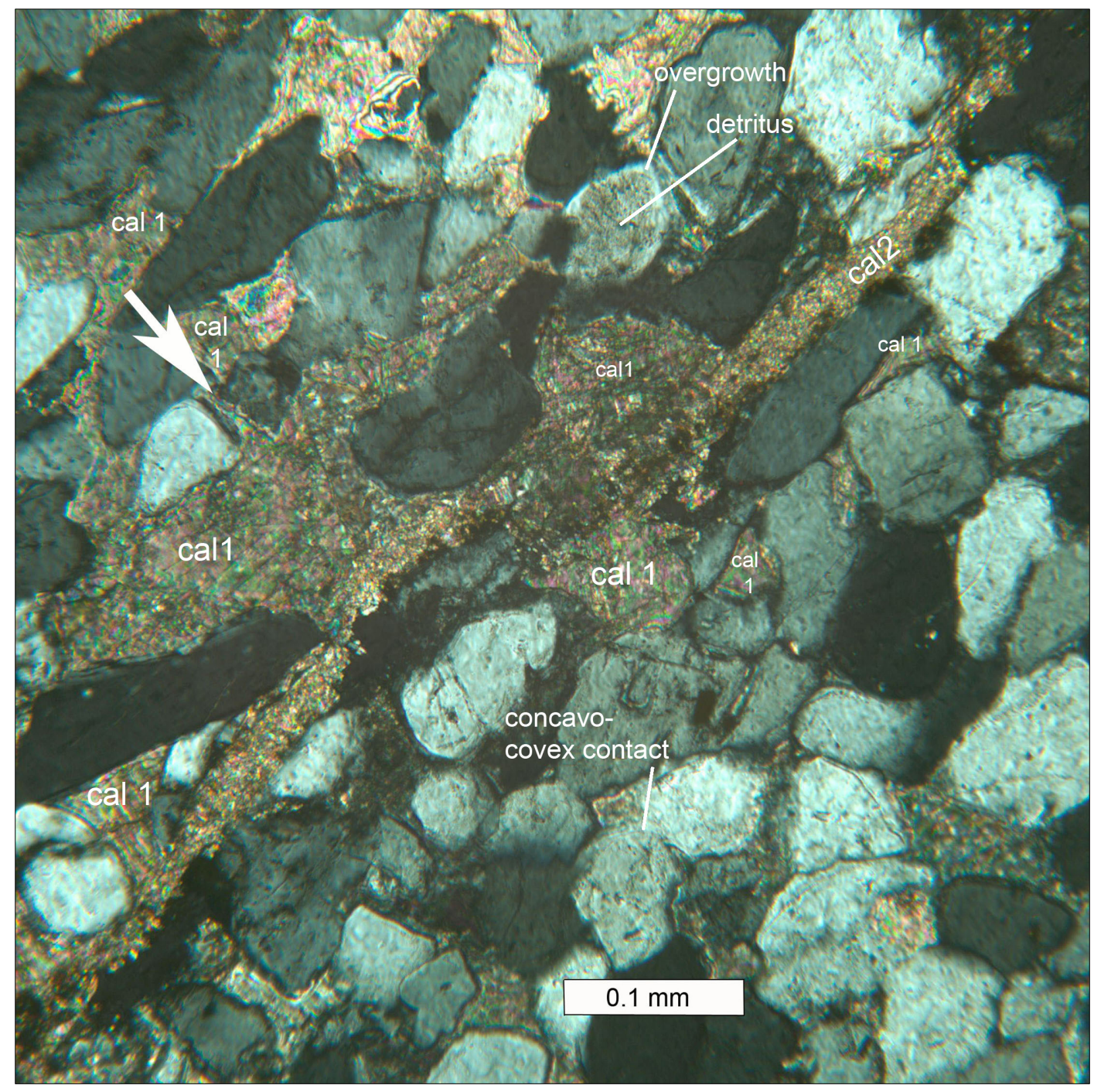

Figure 7. Photomicrograph in transmitted, cross-polarized light, of sandstone from silicified and manganese-mineralized sandstone along the Al-Mudbaie Fault at location 6 (see fig. 3), Rutbah Uplift, Anbar Province, western Iraq. Quartz detritus is (1) overgrown with quartz cement, (2) cemented poikilotopically by a first generation of calcite, and finally (3) cemented by a second, micritic generation of calcite along through-going fractures. The earlier calcite generation (cal1) forms optically continuous crystals as large as $2 \mathrm{~mm}$ in longest dimension enclosing quartz detritus (poikilotopic cement) and, locally, it fills fractures across detrital grains as at the arrow left of center. The later calcite generation (cal2) fills fractures that cut across both detrital quartz grains and calcite 1 grains. 


\section{Location 7-Brecciated Carbonate Rock in the Muhaiwir Formation}

All MVT deposits contain breccias of their carbonate wallrocks. Most can be demonstrated to be gravity collapse breccias, such as:

1. Paleokarst collapse breccias,

2. Breccias produced by differential compaction,

3. Pre-ore breccias accompanying dolomitization,

4. Pre-ore hydrothermal dissolution breccias, or

5. Ore-stage hydrothermal dissolution breccias.

It can be shown at places that breccias originated by mechanisms 1 or 2 and later were overprinted by ore-stage hydrothermal dissolution collapse brecciation.

At location 7, the Middle Jurassic Muhairwir Formation dolostones are exposed with locally chaotic dips, with many small depressions filled with residual concentrations of hematitic sandstone and hematite-kaolinite-veined dolostone. Nearby, downsection within the Ubaid Formation, there are small karst bauxite deposits (Mustafa and others, 1994), and the chaotic dips, hematite, and kaolinite are interpreted to originate from a bauxitic paleoweathering event between Aptian and Albian time (Al-Bassam, 1996). On the flanks of the shallow depression at location 7, Muhaiwir dolostone is intensely fractured and locally crackle-brecciated (terminology from Morrow, 1982) (fig. 8). The breccia- and fracture-fill is white sparry calcite. Breccia clasts are enveloped on all edges by a zone less than $1 \mathrm{~mm}$ thick with intercrystalline goethite. Notably, the iron mineral here is goethite, not hematite.

Carbonate staining of the dolostone breccia by the method of Dickson (1965) reveals that the breccia-fill actually contains two generations of calcite that also were distinguished in thin section. The first generation is white because the calcite is clouded with tiny fluid inclusions, and when stained, turns pure reddish-pink color, characteristic of pure-calcium calcite. The second generation is limpid in thin section, and if stained turns purplish pink, suggesting higher iron concentration in the calcite than the first generation.

Cross-cutting relations observed at this location indicate that hematite, kaolinite, and quartz as secondary cements and veinlets date from a different, probably earlier time, than do goethite and calcite breccia-fill and veinlets. Veinlets of white sparry calcite cut earlier stockworks of hematite-kaolinite veinlets. 


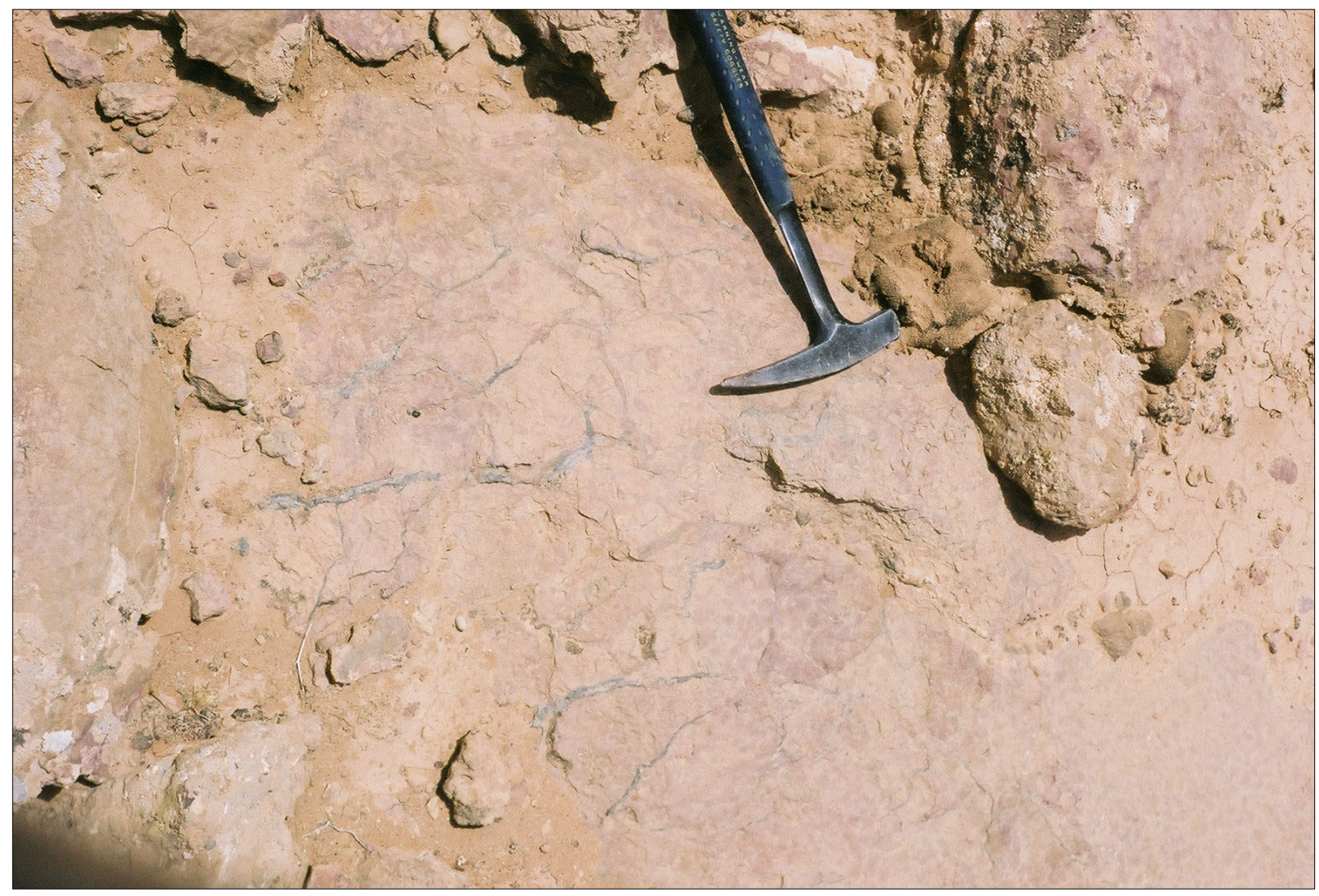

Figure 8. Outcrop photograph showing crackle-brecciated dolostone wallrock on the flank of a small depression that probably sits atop paleokarst and contains hematite-kaolinite-veined dolostone and hematite-quartz-cemented sandstone, Rutbah Uplift, Anbar Province, western Iraq. Hematitic mineralization probably is related to paleokarst bauxite deposits in Ubaid Formation downsection and nearby. Brecciaand veinlet-fill is white sparry calcite. Photograph was taken at location 7 (see fig. 3). Rock hammer shows scale. 


\section{Location 8 -White Sparry Calcite Veinlets}

Hydrothermal carbonate minerals are a conspicuous feature of MVT systems, not only as gangue at the deposits, but throughout the regional aquifers that were used by the MVT fluids (Rowan, 1986; Hayes and others, 1990; Hayes and Anderson, 1992). In some MVT systems, hydrothermal dolomite precipitation alternates, paragenetically, with precipitation of sulfidessphalerite, galena, pyrite, and marcasite at deposits, and generally only pyrite with sparse traces of sphalerite within the regional aquifers (Palmer and Hayes, 1989). The Ozark Region MVT System in northern Arkansas, southern and central Missouri, and eastern Kansas and Oklahoma is such a system. The only calcite in the paragenesis of most Ozark system deposits is from the last paragenetic stages, and from oxygen isotopes, that calcite marks the collapse of the hydrothermal systems when cooler meteoric waters mixed with the brines and cooled and diluted them to shut off the ore-depositing system (Hall and Friedman, 1969). By contrast, the paragenesis of the Illinois-Kentucky-Central Tennessee MVT system was "calcite-stable." In it, the paragenesis is an alternation between hydrothermal calcites and ore sulfides with or without fluorite (Kyle, 1976; Hayes and Anderson, 1992). The hydrothermal calcites alternate in regional aquifer rocks with traces of pyrite. The hydrothermal calcite is easily distinguished from wallrock and other calcite because it is anomalously ferroan and manganoan and very coarsecrystalline. In the field, the hydrothermal calcite weathers to chocolate-brown boxworks of earthy goethite. In the laboratory, the iron content can be made visible by staining by the method of Dickson (1965) (fig. 9).

Prior to fieldwork, it was postulated that any MVT system that affected the rocks of the Rutbah Uplift would be dolomite-stable because the MVT mineralization observed in the deep subsurface of northeastern Saudi Arabia is dolomite-stable. Fieldwork at locations 1 through 7 identified only calcite veinlets, suggesting instead that a calcite-stable MVT system may have operated. That led us to further examine the calcite veinlets at location 8 (table 1, fig. 3).

At location 8, the basal few meters of the Upper Unit Hussainiyat Formation dolostone locally are heavily dedolomitized in a manner similar to that of location 1 . Above those few meters, the outcrops are pure dolostone (mostly fine-crystalline wavy laminated wackestones), and, at places, there are many veinlets of white sparry calcite. At location 8 , several tens of calcite veinlets were examined, and one representative veinlet was sampled. Their appearance is similar to veinlets of white sparry calcite from the Illinois-Kentucky-Central Tennessee MVT system. The Hussainiyat-hosted veinlets have selvages of goethite like some veinlets in the MVT system in the United States. In outcrops of the Illinois-Kentucky-Central Tennessee MVT system, goethite forms pseudomorphs after pyrite, throughout the regional aquifers. The pyrite is interlayered with sphalerite and fluorite, at the deposits. 


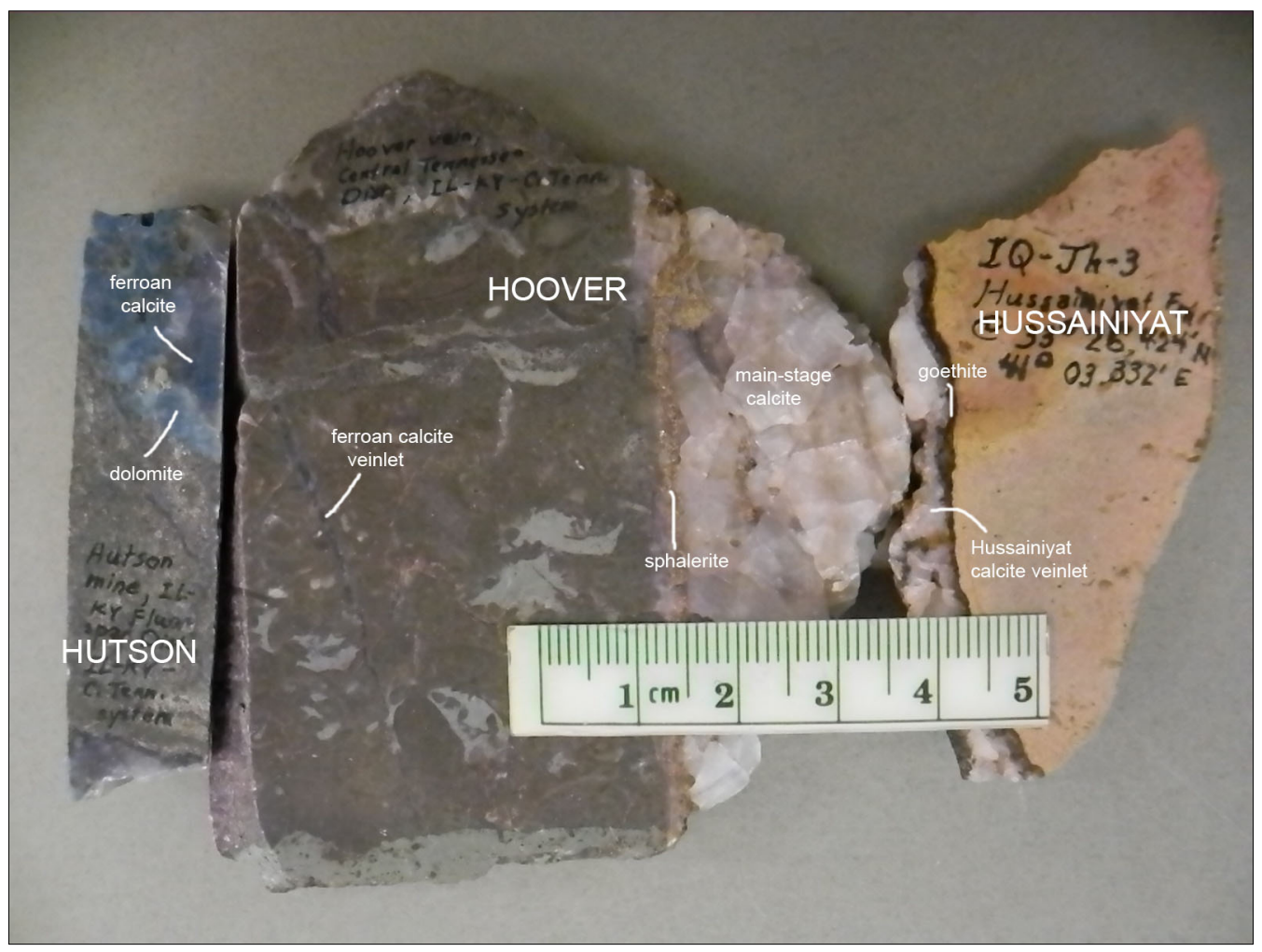

Figure 9. Finely ground slabs stained by the method of Dickson (1965), comparing staining colors of two samples from the Illinois-Kentucky-Central Tennessee Mississippi Valley-Type system, United States (left and center), with sample Jh-3 from dolostone from the Upper Unit of Hussainiyat Formation at location 8 (see fig. 3), Rutbah Uplift, Anbar Province, western Iraq (right). From left, samples are (1) sample from the Hutson mine, Illinois-Kentucky fluorspar district; (2) sample from Hoover vein, Central Tennessee district; and (3) Jh-3. In the Hutson mine sample, the earliest hydrothermal carbonate is dolomite that stains skyblue. That carbonate is followed by calcite that stains dark, nearly indigo-blue, showing it is iron-rich (5.5 mole percent iron carbonate $\left[\mathrm{FeCO}_{3}\right]$ ). A thin veinlet on the left side of the Hoover mine sample (middle slab) is filled with the same relatively early indigo-blue-staining calcite. In that sample, the main-stage calcite in the vein on its right side stains slightly purplish pink (compare calcite color with pure white of the centimeters scale). That calcite contains 2 mole percent $\mathrm{FeCO}_{3}$ and contains, near the vein wall, the main stage of sphalerite (yellow brown). Hussainiyat hydrothermal veinlet calcite, at right, stains nearly identically with Hoover mine main-stage calcite. Hussainiyat sample from location 8 contains about 3.9 mole percent $\mathrm{FeCO}_{3}$. 
When stained by the method of Dickson (1965), Hussainiyat veinlet calcite has a staining color similar to that of certain of the calcite from middle paragenetic stages from the IllinoisKentucky-Central Tennessee MVT system (fig. 9). The staining color in Hussainiyat veinlet calcite suggested an iron content of at least 2 mole percent $\mathrm{FeCO}_{3}$ compared to similarly staining Illinois-Kentucky calcite. Standardless semi-quantitative analyses on EDS from the SEM confirmed that, yielding 1.85 weight percent $\mathrm{Fe}\left(3.9\right.$ mole percent $\mathrm{FeCO}_{3}$ ) in the Hussainiyat veinlet calcite. However, its manganese content $\left(\mathrm{MnCO}_{3}\right)$ was below detection, quite different from typical Illinois-Kentucky MVT calcite (fig. 10, standardless semi-quantitative analysis table in lower left).

Furthermore, the goethite selvages of the Hussainiyat calcite veinlets are not pseudomorphs after an iron sulfide. Instead, the goethite has a skeletal growth texture (fig. 11) forming delicate trellises of goethite that could not possibly be pseudomorphs after earlier minerals. All former space within the skeleton of goethite is filled poikilotopically with the white sparry veinlet calcite in very coarse crystals.

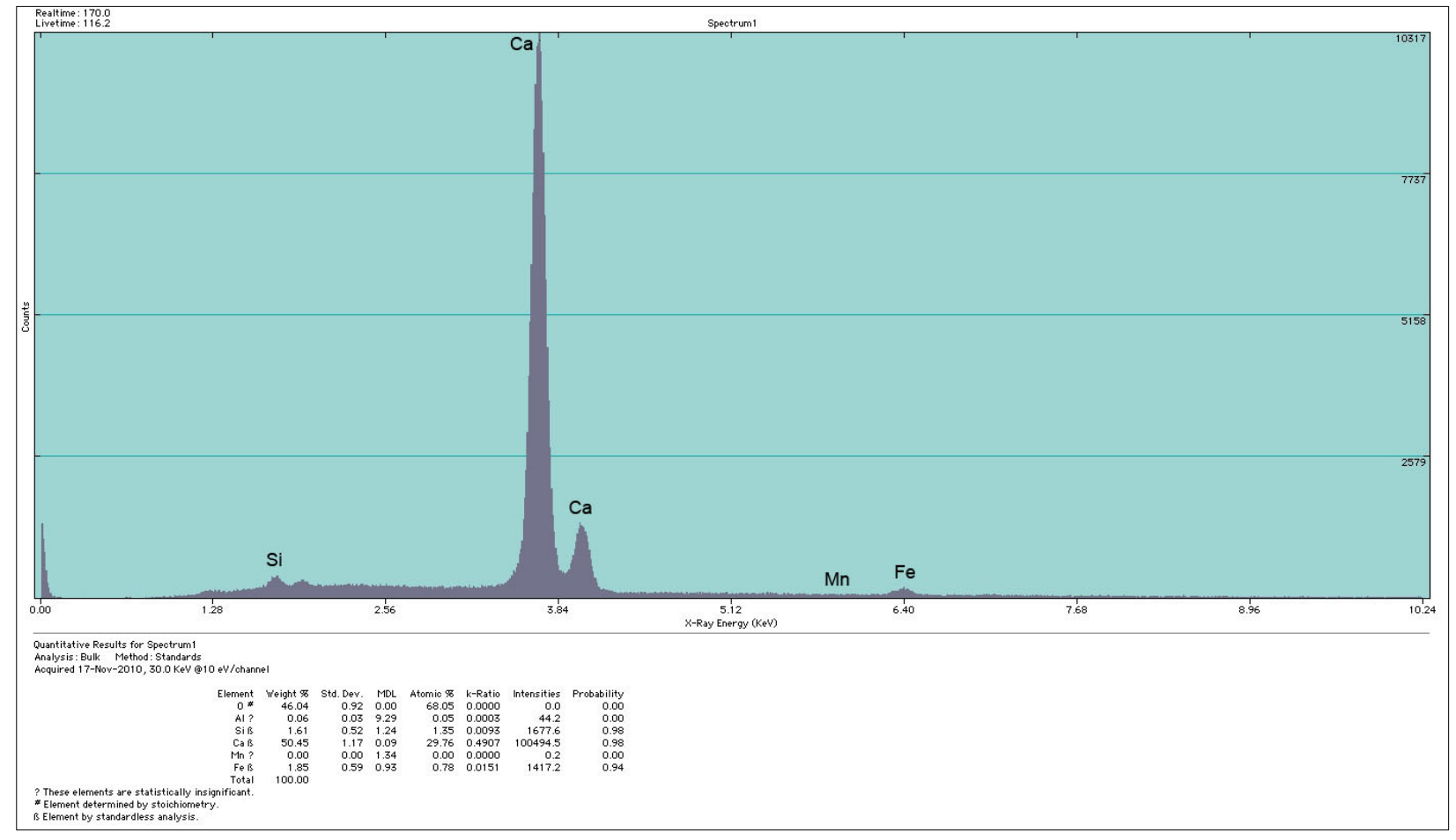

Figure 10. Energy dispersive spectrum and standardless semiquantitative analysis of Hussainiyat veinlet calcite from sample Jh-3 from location 8 (see figs. 3 and 9 [right]), Rutbah Uplift, Anbar Province, western Iraq. The analysis (table at lower left) yields 1.85 weight percent iron (3.9 mole percent iron carbonate $\left.\left[\mathrm{FeCO}_{3}\right]\right)$ but has manganese at a concentration less than the detection limit. 
Even though the goethite did not form as pseudomorphs of iron sulfides, this goethitecalcite veinlet has some similarity to certain goethite from a Mississippi Valley system. Blasch and Coveney (1988) noted goethite within fluid inclusions in calcite from the Jumbo mine in southeastern Kansas, one of the most distal mines of the Ozark Region MVT system. Jumbo mine goethite is, like the Hussainiyat goethite, in skeletal crystals and twinned crystals. The analogy is not perfect - Jumbo mine goethite is within fluid inclusions in calcite; Hussainiyat goethite grew within and towards open space from the wall of the fracture and is included in veinlet-filling calcite.

Blasch and Coveney (1988) conducted microthermometry measurements on the calcite fluid inclusions from the Jumbo mine. The inclusions homogenized by nearly simultaneous dissolution of the goethite and disappearance of the gas bubbles. Blasch and Coveney (1988) noted a strong mode in homogenization temperatures near $105^{\circ} \mathrm{C}$ and a similarly strong mode in salinities of almost 25 equivalent weight percent $\mathrm{NaCl}$. Both these temperatures and salinities are typical of the main stages of MVT deposits, although both are high for the earliest or latest stages. The high salinities are a relatively unique characteristic of MVT fluids. Thus, another test for similarity would be to conduct fluid inclusion microthermometry studies to compare results from the Jumbo mine and from MVT deposits in general, with homogenization temperatures and salinities from inclusions in Hussainiyat calcite veinlets.

Here the similarity ended. The sparry white calcite of veins in the Upper Hussainiyat dolostone is clear in double-polished fluid inclusion plates, and the calcite has only a single type of fluid inclusion. These are one-phase liquid inclusions that commonly are tube-like, $1-2 \mu \mathrm{m}$ wide and greater than $10 \mu \mathrm{m}$ long. The 1-phase liquid inclusions occur within planes crossing the calcite crystals commonly without regard for the calcite cleavage directions, so are interpreted as secondary inclusions. Such one-phase liquid inclusions were trapped at less than about $40{ }^{\circ} \mathrm{C}$ (Roedder, 1984, p. 324), a temperature much less than the homogenizations from Jumbo mine calcite. No inclusions with multiple phases were noted in the Hussainiyat-hosted calcite veinlets, and with these observations, the comparison with the Jumbo mine calcite is poor. 


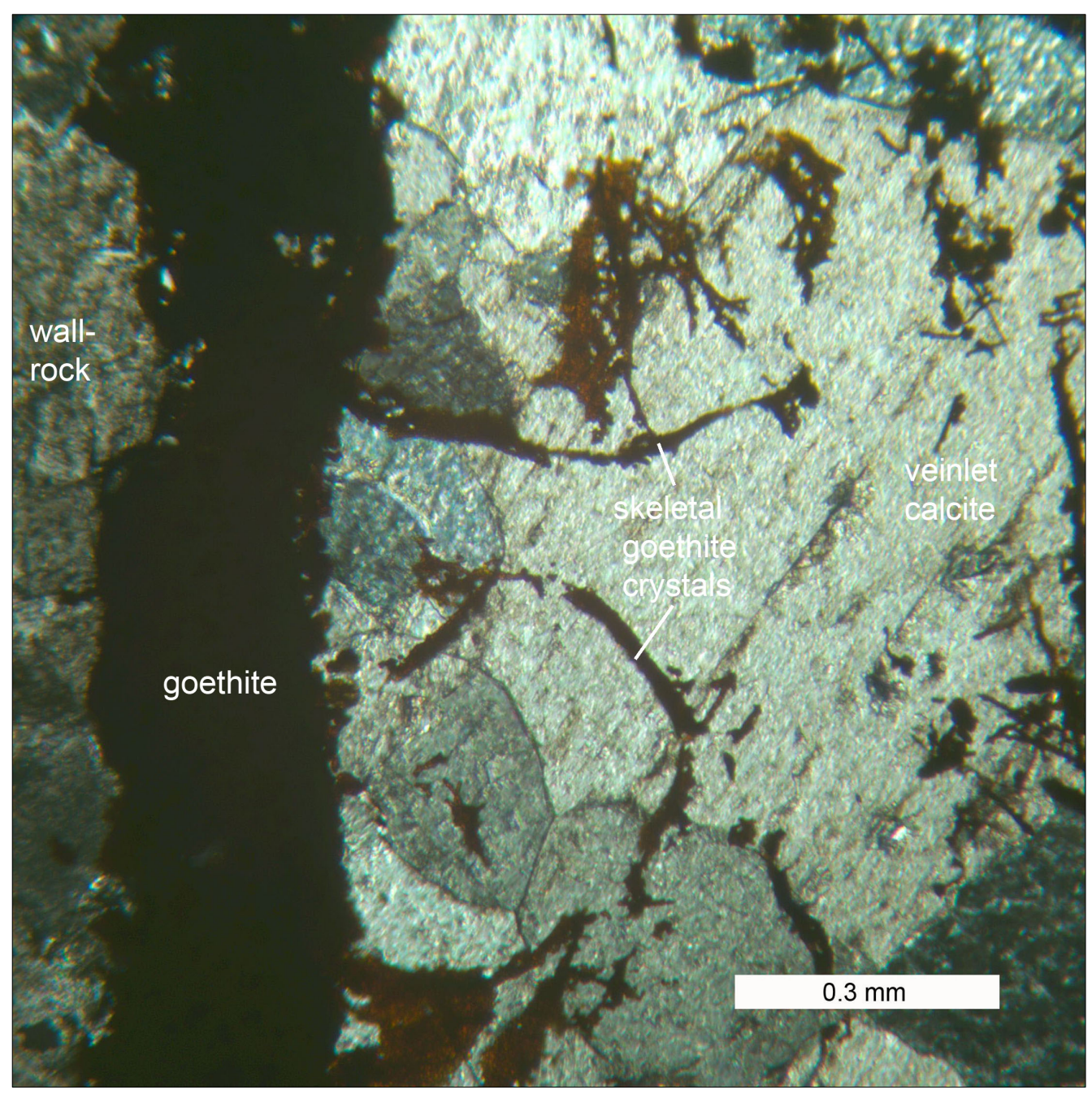

Figure 11. Photomicrograph in transmitted, cross-polarized light of the veinlet margin of the calcitegoethite veinlet in sample Jh-3 from location 8 (see figs. 3 and 9 [right]), Rutbah Uplift, Anbar Province, Iraq. The goethite precipitated in a reaction with the wallrock along the margin of the veinlet and continued to grow into a delicate, twinned trellis of crystals as long as 0.5 millimeters but as thin as 8 microns thick. Coarse veinlet calcite later or simultaneously enclosed the goethite trellis. The goethite is not a pseudomorph of earlier iron sulfides. 


\section{Location 4-Hussainiyat Ironstone Deposit and Its Possible Relation to a MVT Mineralizing System}

The Hussainiyat ironstone deposit was visited at location 4 (table 1, fig. 3) to determine whether it might be "ferruginization" related to a MVT mineralizing system. The ironstone deposit consists of goethite ooids and pelloids, and replaced intraclasts that probably were earlier mud clasts, within a white kaolinitic matrix. The ooids, pelloids, and intraclasts generally are poorly sorted, although probably grain-supported. Some ooids and pelloids are nucleated on well rounded, fine- and medium-sized, quartz sand grains. No veinlets of any kind were observed cutting the ironstone beds over an exposed face more than $20 \mathrm{~m}$ long, and only sparse veinlets of white sparry calcite were observed cutting the overlying lowermost dolostone beds of the Upper Hussainiyat, which, at the ironstone deposit, is a red, sandy dolostone with ghost-ooids. Carbonate mineral staining by the method of Dickson (1965) suggests that the sparry calcite of the veinlets is iron-free-the calcite stains reddish pink. In summary, there was no evidence of a MVT system in the origin of the goethite of the Hussainiyat ironstone deposit. The goethite seems to be syngentic. The Hussainiyat seems to be a fairly typical oolitic ironstone deposit (Maynard and Van Houten, 1991) as also was concluded by Al-Bassam and Tamar-Agha (1998).

\section{Discussion}

A field and laboratory reconnaissance for signs of a Mississippi Valley-type (MVT) leadzinc mineralizing system affecting the rocks of the eastern flank of the Rutbah Uplift in the Western Desert, Iraq, found some features that might indicate that a MVT lead-zinc mineralizing system affected the rocks of the area. However, many of the most diagnostic features of MVT systems were not observed. No very coarse-crystalline hydrothermal saddle dolomite was found, nor was there any hydrothermal mineralization localized at a limestone-dolostone interface. Goethite that formed selvages against the wallrocks of white sparry calcite veinlets did not originate as pseudomorphs of iron sulfides that might form, marking a regional aquifer that was used in the transport of metals in an MVT system. No evidence was found that might suggest that the Hussainiyat oolitic ironstone deposit might be epigenetic and related to an MVT mineralizing system.

The strongest piece of evidence in support of MVT system effects is that the Al-Mudbaie Fault has clearly seen movement of manganiferous fluids along it, now expressed as black manganese oxides in silicified sandstones along the fault. The reconnaissance also observed layer-form colloform goethite that probably is pseudomorphic after iron sulfides, and that goethite is similar in form and field setting to the same mineral from filled sink iron deposits in central Missouri that are a distal expression of the Ozark Region MVT system. The Iraqi layerform, colloform goethite is anomalously rich in nickel, cobalt, and especially molybdenum, suggesting that the iron sulfides may have originated in a regional aquifer used by MVT mineralizing fluids. The calcite from the calcite-goethite veinlets cutting Upper Unit Hussainiyat Formation dolostone at one location has anomalous concentrations of $\mathrm{FeCO}_{3}$ like those in similar veinlets from the Illinois-Kentucky-Central Tennessee MVT system. However, that calcite does not have correspondingly high concentrations of $\mathrm{MnCO}_{3}$. The only fluid inclusions found in that calcite are secondary, one-phase liquid inclusions that were trapped at less than about $40{ }^{\circ} \mathrm{C}$. 
Further work is needed. That work is best conducted examining fresh, unweathered rock. Reconnaissance core drilling would be worthwhile, and if some of the effects seen in this study were due to a MVT system, then the exposures on the eastern flank of the Rutbah Uplift represent distal positions within that MVT system. Although the calcite is iron-bearing in veinlets in the Upper Hussainiyat dolostone, the calcite has fluid inclusions trapped at less than $40{ }^{\circ} \mathrm{C}$. Even the coolest known MVT fluids exceeded $70{ }^{\circ} \mathrm{C}$, and most fluids exceeded $100{ }^{\circ} \mathrm{C}$. Reconnaissance core drilling is recommended about $10 \mathrm{~km}$ northeast from locations 2 and 8 . None of the results from this work suggest what direction to move from the eastern flank of the Rutbah Uplift, but a reasonable direction would be northeastward, toward the hypothesized source of fluids in the foreland basin beneath the Tigris and Euphrates Plain. The northeasterly direction also places the proposed drillhole in a highly faulted zone where the target formations are known to be karstified. Saudi Arabian occurrences suggest that drilling should target the stratigraphic interval from about Muhaiwir Formation up through Nahr Umr Formation. It is known that, in moving eastward, these rocks will descend to depths greater than $1 \mathrm{~km}$ over only tens of km laterally, and Mississippi Valley-type $\mathrm{Pb}-\mathrm{Zn}$ deposits cannot be economically mined by conventional underground methods at depths much greater than $1 \mathrm{~km}$. Existing drillhole information should be consulted to select an initial core drilling site with special attention paid to any mud log descriptions of pyrite, marcasite, and (or) very coarsely crystalline dolomite or calcite. If identifiable MVT hydrothermal carbonates or sulfides are found in a first core hole, exploration by reconnaissance drilling would be worth continuing as depth limitations allow.

\section{Conclusions}

There are pieces of permissive evidence that a Mississippi Valley-Type (MVT) mineralizing system affected Mesozoic rocks on the eastern flank of the Rutbah Uplift, but none of the evidence is considered definitive. If there was a MVT mineralizing system that affected these rocks, the locations visited are in distal positions (from ore mineralization) within that MVT system. Responding to the permissive evidence, we recommend reconnaissance core drilling to obtain unweathered samples and suggest that a first core hole be drilled about 10 kilometers to the northeast from the easternmost field locations visited in this reconnaissance. Location of that hole should be selected based on a search for iron sulfides and very coarsecrystalline carbonates in mud logs of existing drill holes. 


\section{References Cited}

Al-Bassam, K.S., 1996, Contribution to the age of the bauxite-bearing karst deposits, Western Desert, Iraq: Iraqi Geological Journal, v. 29, p. 93-97.

Al-Bassam, K.S., and Hak, J., 2006, Metallic and industrial rocks and minerals, in Jassim, S.Z., and Goff, J.C., eds., Geology of Iraq: Prague, Donlin, p. 288-302.

Al-Bassam, K.S., and Tamar-Agha, M.Y., 1998, Genesis of the Hussainiyat ironstone deposit, Western Desert, Iraq: Mineralium Deposita, v. 33, p. 266-282.

Appold, M.S., and Nunn, J.A., 2005, Hydrology of the Western Arkoma basin and Ozark platform during the Ouachita orogeny-Implications for Mississippi Valley-type ore formation in the Tri-State Zn-Pb district: Geofluids, v. 5, p. 308-325.

Bethke, C.M., 1986, Hydrologic constraints on the genesis of the Upper Mississippi Valley mineral district from Illinois Basin brines: Economic Geology, v. 81, p. 233-249.

Bradley, D.C., and Leach, D.L., 2003, Tectonic controls of Mississippi Valley-type lead-zinc mineralization in orogenic forelands: Mineralium Deposita, v. 38, p. 652-667.

Blasch, S.R., and Coveney, Jr., R.M., 1988, Goethite-bearing brine inclusions, petroleum inclusions, and the geochemical conditions of ore deposition at the Jumbo mine, Kansas: Geochimica et Cosmochimica Acta, v. 52, p. 1,007-1,017.

Broomhall, R.W., and Allan, J.R., 1987, Regional caprock-destroying dolomite on the Middle Jurassic to Early Cretaceous Arabian Shelf: Society of Petroleum Engineers Formation Evaluation, v. 2, no. 4, p. 435-441.

Coleman, R.G., 1977, Geologic background of the Red Sea, in Red Sea Research, 1970-1975: Saudi Arabian Directorate General of Mineral Resources Mineral Resources Bulletin 22, p. C1-C9.

Dickson, J.A.D., 1965, A modified staining technique for carbonates in thin section: Nature, v. 205, p. 587.

Erickson, R.L., Mosier, E.L., Odland, S.K., and Erickson, M.S., 1981, A favorable belt for possible mineral discovery in subsurface Cambrian rocks in southern Missouri: Economic Geology, v. 76, p. 921-933.

Farr, M.R., 1989, Compositional zoning characteristics of late dolomite cement in the Cambrian Bonneterre Formation, Missouri-Implications for parent fluid migration pathways:

Carbonates and Evaporites, v. 4, p. 177-194.

Grawe, O.R., 1945, Pyrites deposits of Missouri: Missouri Geological Survey and Water Resources, v. XXX, Second Series, 482 p.

Gregg, J.M., 1985, Regional epigenetic dolomitization in the Bonneterre Dolomite (Cambrian), southeastern Missouri: Geology, v. 13, p. 503-506.

Hall, W.E., and Friedman, I., 1969, Oxygen and carbon isotopic composition of ore and host rock of selected Mississippi Valley deposits: U.S. Geological Survey Professional Paper 650C, p. C140-C148.

Hasan, F.A., 1993, The relation of iron oxide concentration with dedolomitization and recrystallization processes of dolomite, Hussainiyat Formation (Lower Jurassic), Hussainiyat and North Rutba, Iraq: Iraqi State Company for Geological Survey and Mining archival report, 14 p. [in Arabic.]

Hayes, T.S., and Anderson, W.H., 1992, Regionwide correlation of the hydrothermal paragenesis of the Illinois-Kentucky fluorspar district [abs.], in Goldhaber, M.B., and Eidel, J.J., eds., Mineral resources of the Illinois Basin in the context of basin evolution: U.S. Geological Survey Open-File Report 92-1, p. 19-22. 
Hayes, T.S., Kadi, K.A., Balkhiyour, M.B., Siddiqui, A.A., and Beshir, Z., 2000, Phanerozoic sediment-hosted base-metal mineralizing systems in Saudi Arabia: Saudi Arabian Ministry of Petroleum and Mineral Resources Technical Report USGS-TR-00-3, 29 p.

Hayes, T.S., Palmer, J.R., and Rowan, E.L., 1990, Correlation of hydrothermal dolomite generations across the Mississippi Valley-type mineralizing system of the Ozark region [abs.], in Pratt, W.P., and Goldhaber, M.B., eds., U.S. Geological Survey-Missouri Geological Survey Symposium-Mineral-resource potential of the Midcontinent, Programs and Abstracts: U.S. Geological Survey Circular 1043, p. 10.

Kyle, J.R., 1976, Brecciation, alteration, and mineralization in the Central Tennessee Zinc District: Economic Geology, v. 71, p. 892-903.

Leach, D.L., and Rowan, E.L., 1986, Genetic link between Ouachita foldbelt tectonism and the Mississippi Valley-type lead-zinc deposits of the Ozarks: Geology, v. 14, p. 931-935.

Leach, D.L., Taylor, R.D., Fey, D.L., Diehl, S.F., and Saltus, R.W., 2010, A deposit model for Mississippi Valley-type lead-zinc ores: U.S. Geological Survey Scientific Investigations Report 2010-5070-A, 52 p.

Leach, D.O., Sangster, D.F., Kelley, K.D., Large, R.R., Garvin, G., Allen, C.R., Gutzmer, J., and Walters, S., 2005, Sediment-hosted lead-zinc deposits: a global perspective: Society of Economic Geologists, Economic Geology One Hundredth Anniversary Volume, 1905-2005, p. 561-607.

Maynard, J.B., and Van Houten, F.B., 1992, Descriptive model of oolitic ironstones, in Bliss, J.D., ed., Developments in mineral deposit modeling: U.S. Geological Survey Bulletin 2004, p. $39-40$.

Morrow, D.W., 1982, Descriptive field classification of sedimentary and diagenetic breccia fabrics in carbonate rocks: Canadian Petroleum Geologists Bulletin, v. 30, p. 227-229.

Mustafa, M., Naif, A., Jibrail, A., Hussain, D., Ahmad, M., Al-Kadhimi, J., Misconi, H., Saeed, L., Zarrag, G., and Abdul Sattar, M., 1994, The results of prospecting - exploration on bauxite deposits in northern Hussainiyat, Western Desert: Iraqi State Company for Geological Survey and Mining Internal Report 2276.

Palmer, J.R., and Hayes, T.S., 1989, Late Cambrian lithofacies and their control on the Mississippi Valley-type mineralizing system in the Ozark Region [abs.], in Schindler, K.S., ed., USGS Research on Mineral Resources - 1989, Program and abstracts, Fifth annual V.E. McKelvey Forum on Mineral and Energy Resources: U.S. Geological Survey Circular 1035, p. 51-53.

Plumlee, G.S., Goldhaber, M.B., and Rowan, E.L., 1995, The potential role of magmatic gases in the genesis of Illinois-Kentucky fluorspar deposits-Implications from chemical reaction path modeling: Economic Geology, v. 90, p. 999-1,011.

Plumlee, G.S., Leach, D.L., Hofstra, A.H., Landis, G.P., Rowan, E.L., and Viets, J.G., 1994, Chemical reaction path modeling of ore deposition in Mississippi Valley-type $\mathrm{Pb}$-Zn deposits of the Ozark Region, U.S. Midcontinent: Economic Geology, v. 89, p. 1,361-1,383.

Pratt, W.P., Erickson, R.L., Jenson, S.K., and Hastings, D.A., 1986, The Rolla and Springfield, Missouri, CUSMAP resource assessments, in Cargill, S.M., and Green, S.B., eds., Prospects for mineral resource assessments on public lands-Proceedings of the Leesburg workshop: U.S. Geological Survey Circular 980, p. 140-159.

Radke, B.M., and Mathis, R.L., 1980, On the formation and occurrence of saddle dolomite: Journal of Sedimentary Petrology, v. 50, p. 1,149-1,168.

Roedder, E., 1984, Fluid inclusions: Mineralogical Society of America Reviews in Mineralogy, v. 12,644 p. 
Rowan, E.L., 1986, Cathodoluminescent zonation in hydrothermal dolomite cementsRelationship to Mississippi Valley-type lead-zinc mineralization in southern Missouri and northern Arkansas, in Hagni, R.D., ed., Process mineralogy VI: Warrendale, Pennsylvania, The Metallurgical Society of American Society of Mining, Metallurgical, and Petroleum Engineers, p. 69-87.

Sissakian, V.K., compiler, 2000, Geological map of Iraq, 3rd edition: Iraqi State Company of Geological Survey and Mining (GEOSURV), scale: 1:1,000,000.

Sissakian, V.K., compiler, 2007, Geological map of Iraq, 4th edition: Iraqi State Company of Geological Survey and Mining (GEOSURV), scale: 1:1,000,000.

Smith, D.C., 1984a, Cover rocks project_Exploration of the Jauf Formation in the Al-Huj area: Saudi Arabian Deputy Ministry of Mineral Resources Open-File Report RF-OF-04-24, 29 p.

Smith, D.C., 1984b, Cover rocks project-Exploration of the Paleozoic rocks of the Tabuk region: Saudi Arabian Deputy Ministry for Mineral Resources Open-File Report RF-OF-0426, $18 \mathrm{p}$.

Smith, D.C., and Allen, M.C., 1984, Cover rocks project investigations in the Tayma region, NW and NE Hijaz: Saudi Arabian Deputy Ministry of Mineral Resources Open-File Report RFOF-04-18, $47 \mathrm{p}$.

Snyder, F.G., 1968, Geology and mineral deposits, Midcontinent United States, in Ridge, J.D., ed., Ore deposits of the United States, 1933-1967 (Graton-Sales volume): New York, American Institute of Mining, Metallurgical and Petroleum Engineers, v. 1, p. 257-286.

Stoffell, B., Appold, M.S., Wilkinson, J.J., McClean, N.A., and Jeffries, T.E., 2008, Geochemistry and evolution of Mississippi Valley-type mineralizing brines from the Tri-State and Northern Arkansas districts determined by LA-ICP-MS microanalysis of fluid inclusions: Economic Geology, v. 103, p. 1,411-1,436.

Sverjensky, D.A., 1981, The origin of a Mississippi Valley-type deposit in the Viburnum Trend, southeast Missouri: Economic Geology, v. 76, p. 1,848-1,872.

Tobia, F.H., 1983, Geochemistry and mineralogy of the iron deposits of the Ga'ara Formation in the Iraqi Western Desert: Baghdad, Iraq, University of Baghdad, Master's thesis.

Vaslet, D., Janjou, D., Robelin, C., Al-Muallem, M.S., Halawani, M.A., Brosse, J.-M., Breton, J.-P., Courbouleix, S., Roobol, M.J., and Dagain, J., 1994, Geologic map of the Tayma quadrangle, sheet 27C, Kingdom of Saudi Arabia: Saudi Arabian Deputy Ministry for Mineral Resources Map GM-134, scale 1:250,000 (with a pamphlet of explanatory notes, 51 p.).

Vaslet, D., Manivit, J., Le Nindre, Y.-M., Brosse, J.-M., Fourniguet, J., and Delfour, J., 1983, Geologic map of the Wadi Ar Rayn quadrangle, sheet 23H, Kingdom of Saudi Arabia: Saudi Arabian Deputy Ministry for Mineral Resources Map GM-63A, scale: 1:250,000 (with a pamphlet of explanatory notes, $46 \mathrm{p}$ ). 
Publishing support provided by the U.S. Geological Survey Publishing Network, Tacoma Publishing Service Center

For more information concerning the research in this report, contact the Geology, Minerals, Energy, \& Geophysics Science Center U.S. Geological Survey, c/o University of Arizona ENRB Building, 520 N. Park Ave, Rm 355

Tucson, Arizona 85719-5035

http://geomaps.wr.usgs.gov/gmeg/ 
인

言

3 